\title{
Promising Nanoparticle-Based Heat Transfer Fluids-Environmental and Techno-Economic Analysis Compared to Conventional Fluids
}

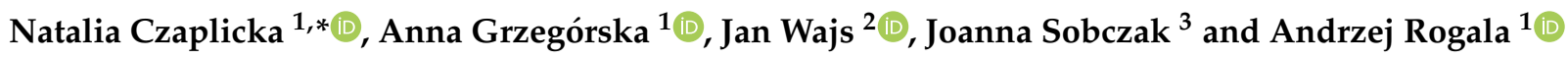 \\ 1 Department of Process Engineering and Chemical Technology, Faculty of Chemistry, Gdansk University of \\ Technology, Narutowicza 11/12, 80-233 Gdansk, Poland; anna.grzegorska@pg.edu.pl (A.G.); \\ andrzej.rogala@pg.edu.pl (A.R.) \\ 2 Institute of Energy, Faculty of Mechanical Engineering and Ship Technology, Gdansk University of \\ Technology, Narutowicza 11/12, 80-233 Gdansk, Poland; jan.wajs@pg.edu.pl \\ 3 Research and Development Joanna Sobczak, Różnowo 8, 14-240 Susz, Poland; joasobczak@outlook.com \\ * Correspondence: natalia.czaplicka@pg.edu.pl
}

\section{check for} updates

Citation: Czaplicka, N.; Grzegórska, A.; Wajs, J.; Sobczak, J.; Rogala, A. Promising Nanoparticle-Based Heat Transfer Fluids-Environmental and Techno-Economic Analysis Compared to Conventional Fluids. Int. J. Mol. Sci. 2021, 22, 9201. https://doi.org/10.3390/ ijms22179201

Academic Editor:

Senentxu Lanceros-Mendez

Received: 30 July 2021

Accepted: 24 August 2021

Published: 25 August 2021

Publisher's Note: MDPI stays neutral with regard to jurisdictional claims in published maps and institutional affiliations.

Copyright: (c) 2021 by the authors. Licensee MDPI, Basel, Switzerland. This article is an open access article distributed under the terms and conditions of the Creative Commons Attribution (CC BY) license (https:/ / creativecommons.org/licenses/by/ $4.0 /)$.

\begin{abstract}
Providing optimal operating conditions is one of the major challenges for effective heating or cooling systems. Moreover, proper adjustment of the heat transfer fluid is also important from the viewpoint of the correct operation, maintenance, and cost efficiency of these systems. Therefore, in this paper, a detailed review of recent work on the subject of conventional and novel heat transfer fluid applications is presented. Particular attention is paid to the novel nanoparticle-based materials used as heat transfer fluids. In-depth comparison of environmental, technical, and economic characteristics is discussed. Thermophysical properties including thermal conductivity, specific heat, density, viscosity, and Prandtl number are compared. Furthermore, the possible benefits and limitations of various transfer fluids in the fields of application are taken into account.
\end{abstract}

Keywords: nanoparticles; nanofluids; heat transfer fluids; heating and cooling systems

\section{Introduction}

Providing optimal operating conditions is one of the major challenges for effective heating or cooling systems. The great importance of these systems is to enhance the rate of heat or cold transfer by the application of advanced working fluids. However, several operation and maintenance key criteria must be met when the usage of transfer fluids is considered. Heat transfer fluids (HTFs) are widely used in many industrial and consumer applications and are characterized by two groups of parameters, physicochemical and thermal properties. Among the physicochemical parameters, the most important are kinematic viscosity, flash point, and pour point $[1,2]$. Viscosity determines the flow in the system, and to ensure sufficiently small temperature gradients between the heat carrier and the heat transfer surface, it is necessary to provide a turbulent flow, characterized by a Reynolds number above 2100 in linear channels with circular cross sections. The flash point determines the possibility of HTF inflammation in contact with heated surfaces. Therefore, it is important for safety, for example, in the event of leaks in the system. Furthermore, the pour point and viscosity are important for starting the system, especially in low-temperature conditions. The minimum start-up temperature should be about 5$10{ }^{\circ} \mathrm{C}$ above the pour point, or it is determined by the minimum temperature at which the fluid viscosity becomes the maximum allowable value for the pumps installed in the system. Thus, the high viscosity of the fluid is undesirable, due to the fact that this affects the lowest start-up temperature of the system and the pumping power, and the pressure loss of the system [3]. The possibility of using a given HTF in a specific heat transfer system is determined by its thermal properties, i.e., those that are taken into account in the calculations of heat transfer systems. These are density, kinematic, and 
dynamic viscosity in the operating temperature range, specific heat, thermal conductivity, and Prandtl number [2]. The Prandtl number is a criterion number that characterizes the similarity of the physical properties of fluids in heat transfer processes. It represents the ratio of momentum diffusivity to thermal diffusivity in a fluid. A high value of the Prandtl number means that the fluid has a high ability to transfer momentum and a low ability to transfer heat, while a low value of this number indicates a low ability to transfer momentum and a high ability to transfer heat [4].

Depending on the field of technology, specific requirements are imposed on the properties of HTFs. For example, in ferrous and non-ferrous metallurgy, high thermal stability is a desirable property in HTFs, while in the space rocket industry, low density and low volatile liquids are required $[5,6]$. However, there are characteristics that should characterize the fluid used as HTF, regardless of the system in which it is to be applied, as shown in Figure 1. First, the HTFs must show a very good heat transfer capacity in the selected temperature range, i.e., high specific heat and a high thermal conductivity coefficient [1]. In addition, they should be characterized by high thermal and thermooxidative stability, compatibility with construction materials used in heating systems, and non-toxicity $[7,8]$. HTFs should not be prone to secretion and deposition of sediments on the walls of the system. It is also important to have the appropriate viscosity in the operating temperature range and the pour point adjusted to the conditions to which the system may be exposed [9]. The life charge of the fluid is also important. A good HTF is considered to have a useful life of a charge in the range of 35,000 to 40,000 effective working hours [10]. Currently, a priority trend in heat exchange technology is the search for compounds and the creation of fluid compositions that have the desired combination of key physicochemical properties to solve unconventional problems. Finally, economic features such as the availability and low cost of HTFs should be taken into account.

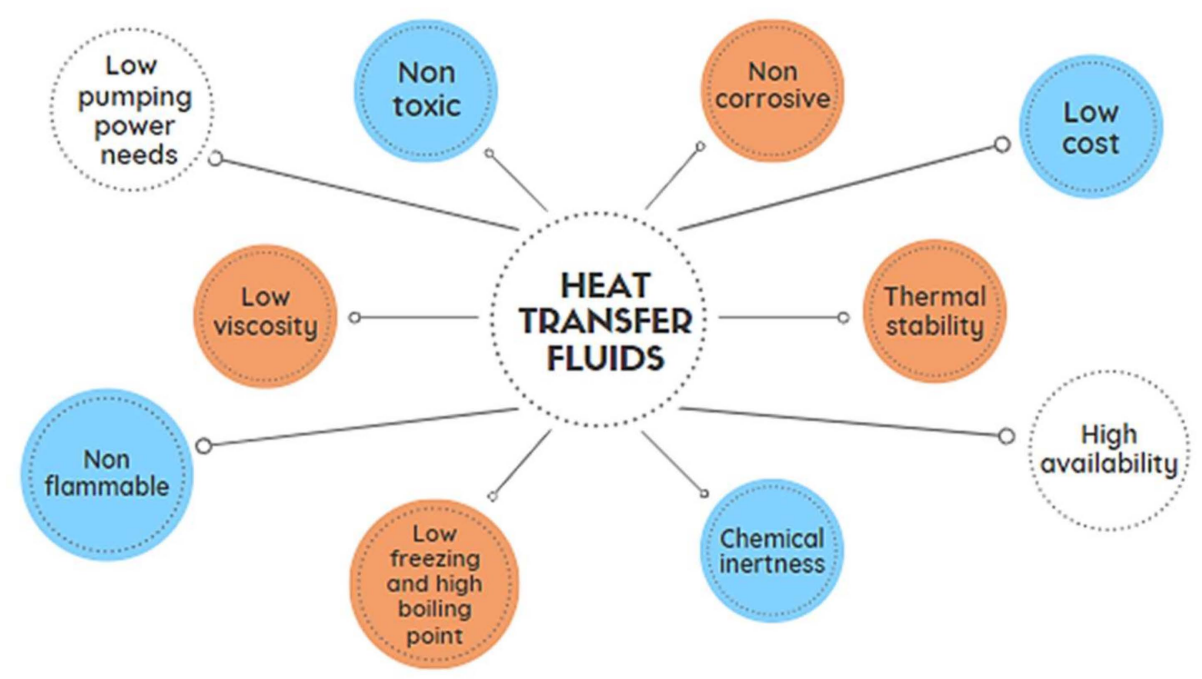

Figure 1. Characteristics of the ideal HTFs.

As the topic of heating and cooling is present in practically every area of industry, it is not surprising that for years, heat transfer fluids have attracted a lot of attention. There are many reviews of heat transfer fluids in the literature that have been developed from different viewpoints. Many of them refer to HTFs used in solar power technology [1,11-18], the use of nanofluids and their modifications [19-30], and ionic liquids [5,10,31-34] as HTFs, and the analysis of commercial HTFs $[35,36]$. However, despite extensive research and analysis, the most popular HTFs in most industrial applications are still conventional media, and no comparison has been made between conventional HTFs and alternative media including nanoparticle-based HTFs in the context of industrial applications. Therefore, the aim of this review is to perform an in-depth comparison of the environmental, technical, and economic characteristics of traditional and nanoparticle-based heat transfer fluids. 
Furthermore, the possible benefits and limitations and the branch of applications of various HTFs are taken into account. This paper focuses on the latest literature reports (mainly from the last five years) on novel HTFs and compares them with commonly and widely used traditional media. Thanks to this, it is possible to highlight the existing problems in the field of industrial HTFs, as well as to determine the direction in which research on new solutions should go to solve the current limitations. The number of articles cited in our work by years of publication is presented in Figure 2.

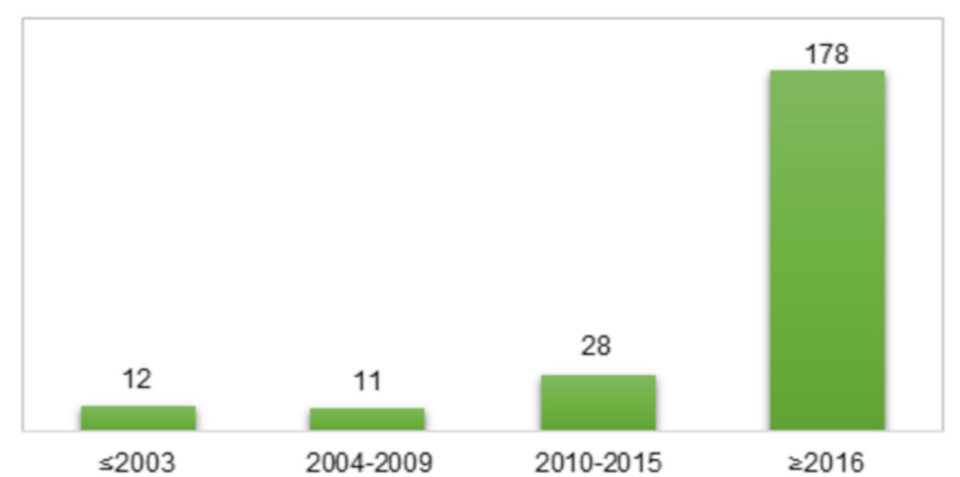

Figure 2. Number of articles cited in this review by year of publication.

\section{Conventional HTFs}

Both liquid and gaseous heat transfer fluids are commonly used, which can be classified into several categories. In terms of the specific applications of HTFs, the classification according to the operating temperature range seems most appropriate. Then, four basic categories of liquids are distinguished [9], which are presented in Figure 3. The most common industrial heat transfer fluids are oil heat carriers, including deeply refined mineral oils with added inhibitors, synthetic polyolefin-type hydrocarbons, aromatic hydrocarbons without alkyl side chains, esters of carboxylic acids and polyhydric alcohols, silicones, silicate esters and alkyl borates $[6,37]$. Synthetic oils, such as Therminol ${ }^{\circledR}$ VP-1 or Dowtherm ${ }^{\circledR}$ A, offer the widest temperature range in which they can be used [38]. Nevertheless, they are toxic and highly flammable, which poses a threat to both plant operators and the environment [39]. In addition, they have high vapor pressures that significantly exceed the atmospheric pressure. This makes their use as thermal storage media difficult due to the necessity to apply impractically large pressure vessels [40]. Furthermore, heating oils as heat carriers should only be used in systems with forced circulation. Systems using only natural convection do not provide enough rapid flow to prevent local overheating and decomposition of the oil. Therefore, finding an alternative to replace the currently implemented HTFs is an important issue that allows for reducing risk, but also reducing costs and improving the efficiency of installations [36]. This chapter briefly characterizes conventional HTFs with regard to their major disadvantages, advantages, and limitations, their thermophysical properties, and the applications in which they are used. 


\section{HEAT TRANSFER FLUIDS}

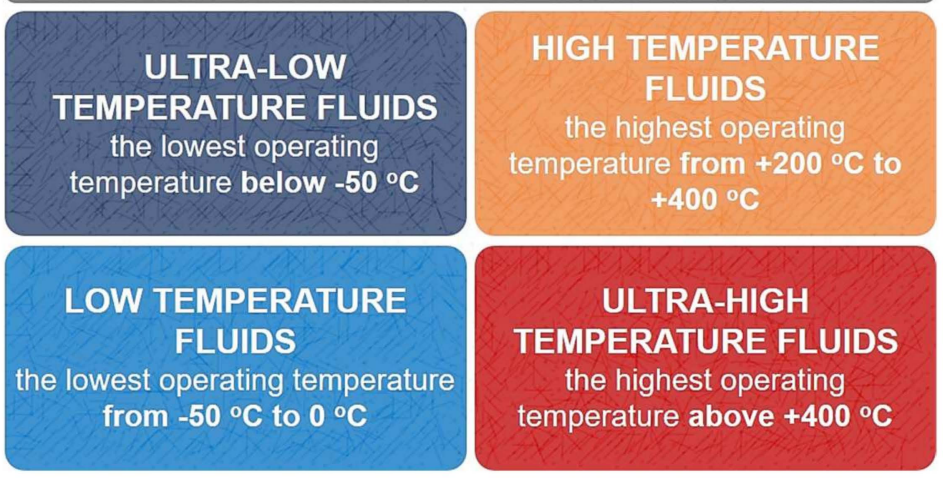

Figure 3. Basic categories of HTFs and their operating temperatures.

\subsection{Air}

The first and most basic example of a heat transfer medium is air. Air has certain advantages, including its non-corrosive nature and its non-vulnerability to freezing and boiling $[2,16]$. Furthermore, air is practically freely available, cost-free, non-polluting and practically does not have an upper operating temperature limit [41-43]. Moreover, it is an important HTF from the viewpoint of environmental safety, because leakages do not cause any problems compared to other HTFs, such as molten salt spills or mineral oil spills $[43,44]$. However, its most significant limitation is its lower thermal conductivity (low air heat transfer rate) and volumetric heat capacity [45]. Due to the relatively low heat capacity, it could not be used for domestic water heating purposes [2]. Furthermore, air must be pressurized or fed through very large pipes. Good et al. [41] proposed the application of air as a heat transfer fluid in a commercial concentrating solar power (CSP) plant with a peak thermal capacity of $3.9 \mathrm{MW}_{\text {th. }}$. Furthermore, the authors claimed that the application of air as an HTF enables the application of a proven and inexpensive thermal energy storage (TES) concept based on a packed bed of rocks. Meanwhile, Li et al. performed the analysis of TES using air as the heat transfer fluid working at $+500{ }^{\circ} \mathrm{C}$. Cinoacca et al. [46] proposed the use of compressed air as a working fluid in a parabolic trough CSP plant with TES. The authors concluded that the application of compressed air allows one to increase the air temperature at the solar field inlet and to reduce the solar collector's length. An installation with applied compressed air at $30 \mathrm{bar}$ and a $1 \mathrm{~kg} / \mathrm{s}$ mass flow rate with a maximum temperature equal to $+580^{\circ} \mathrm{C}$ produces about $170 \mathrm{~kW}$ of mechanical power. However, the main limitations of this technology were the low heat transfer coefficient of air compared to a liquid HTF and the need to pressurize the gas. Toro et al. [47] pointed out that air can be used as the working fluid in solar-heated CSP plants as an alternative HTF, thus reducing maintenance operations and providing the power section with a higher degree of flexibility.

\subsection{Halogenoalkanes}

Alkyl halides such as methylene chloride, trichloroethylene (TCE) and hydrofluorocarbons are commonly used HTFs with operating temperatures below $-50{ }^{\circ} \mathrm{C}$ [48]. These substances are non-flammable and non-corrosive, while those containing chlorine (methylene chloride, TCE) are highly toxic [49]. Therefore, they are systematically removed from use to eliminate them. Fluorine derivatives such as hydrofluoroethers or perfluorocarbon ethers exhibit several unique properties which make them suitable for use as ultra-low temperature HTFs. First of all, they are non-toxic and non-flammable. Moreover, some of these liquids have a very low freezing point and a low viscosity at low temperatures. On the other hand, they are definitely more expensive than their substitutes. Additionally, because of the very low surface tension of these compounds, there is a risk of leakage in the installations, which increases the cost of the 
process. Another disadvantage of low-freezing-point fluoroalkanes is the significantly lower boiling point compared to other heat transfer fluids. These compounds can be used in the temperature range from -100 to $+150^{\circ} \mathrm{C}$.

\subsection{Water/Steam}

Similarly to air, water has good physical properties to be used as a heat transfer medium [50]. The most important characteristics of water are high specific heat $(4185 \mathrm{~J} /(\mathrm{kg} \cdot \mathrm{K}))$, availability, low viscosity, non-toxicity, and low cost [51,52]. However, the main problems with it are related to the corrosive nature and freezing below $0{ }^{\circ} \mathrm{C}$. Furthermore, water is chemically stable at a high temperature, but under normal pressure at $+100{ }^{\circ} \mathrm{C}$, it undergoes a phase transition from the liquid to gas phase. Thus, in the temperature range from 0 to $+100{ }^{\circ} \mathrm{C}$, water is the best fluid for heat transfer. However, when it is necessary to use a heat carrier in a wider temperature range, where the lowest temperature is much lower than $0{ }^{\circ} \mathrm{C}$, the addition of water-soluble organic compounds or inorganic salts is most often used to lower the freezing point. Then, water solutions of glycols (ethylene and propylene), alcohols (methanol, ethanol, isopropanol), or sodium, potassium, or calcium chloride, formate and acetate are used. However, the use of aqueous solutions of such substances allows the boiling point to be slightly higher than the boiling point of pure water, i.e., $+100^{\circ} \mathrm{C}$. To lower the freezing point of water, salt is often added, for example, calcium chloride or sodium chloride [53]. For example, an aqueous $\mathrm{CaCl}_{2}$ solution with a concentration of $29.9 \mathrm{wt} \%$ has a freezing point of $-55^{\circ} \mathrm{C}$. Such solutions are non-flammable and non-toxic. However, they are highly corrosive and at temperatures below $-20^{\circ} \mathrm{C}$, the addition of salt reduces the efficiency of heat transfer efficiency compared to pure water [54].

Water has a higher specific density, heat capacity, and thermal conductivity than steam. The limitation resulting from this is the compromise between the high pressure required for high temperature operation and induced technology difficulties, such as the necessarily thick walls of pipes, which is an obstacle to heat transfer. Furthermore, the upper limits at which water can be used as a HTF in a saturated state in thermodynamic cycles are $+374{ }^{\circ} \mathrm{C}$ and 221 bar, when it reaches a supercritical level. Despite many beneficial properties, pure water/steam has not often been described in the recent literature as a HTF. Montes et al. [55] compared the application of oil, water/steam and molten salts as a HTF for parabolic trough collectors, and the water/steam system has the highest nominal overall efficiency. Meanwhile, Edwards and Bindra [56] proposed the use of saturated steam as a HTF for TES in a packed bed. Furthermore, the authors performed the analysis of air as HTF under the same conditions. It was concluded that the rate of steam injection has a significant effect on the modes of heat transfer, advection, and diffusion. In the case of steam injection, the wall heat loss rate was much lower than the heat injection rate, while for hot air injection, the wall heat loss rate was comparable to the heat injection rate. This fact was related to essentially higher fractional heat losses.

\subsection{Hydrocarbons}

The first group of hydrocarbons used as ultra-low temperature HTFs are aromatic hydrocarbons. The most common is diethylbenzene, which can be used in the temperature range from -70 to $+260^{\circ} \mathrm{C}$ [57]. This compound has very good heat transfer characteristics and high thermal stability at low temperatures [35]. However, the main disadvantage of diethylbenzene is its toxicity. It also has an unpleasant smell that is a nuisance to the employees. Generally, low aromatic hydrocarbons have a freezing point below $-80^{\circ} \mathrm{C}$ and typically such compounds are used in the temperature range above $-70^{\circ} \mathrm{C}$ in hermetically sealed systems [58]. The second group consists of aliphatic hydrocarbons of the paraffinic and isoparaffinic type, called aliphatic compounds based on petroleum. These types of HTFs do not form dangerous degradation by-products. Most of them have a low odor and are not toxic through skin contact or ingestion. Despite these advantages, aliphatic hydrocarbons are not widely used as ultra-low-temperature heat transfer agents [59] due 
to their high low-temperature viscosity and their significantly lower thermal stability compared to aromatic hydrocarbons. Some of the liquids based on isoparaffin (having 12 to 14 carbons) can be used in the temperature range of -60 to $+150{ }^{\circ} \mathrm{C}$ [35]. These compounds are preferred in the food and pharmaceutical industries where non-toxicity is paramount. Another class of hydrocarbons is naturally derived terpenes, including D-limonene [60]. This compound is the most preferred among other monocycloterpenes because of its low viscosity at low temperatures. It is obtained by distilling orange oil obtained from citrus peels [61,62], and is classified as a safe and environmentally harmless HTF, so it is usually used in the pharmaceutical and food industries. The solidification point of D-limonene is $-78{ }^{\circ} \mathrm{C}$, and below this temperature it has a dense gel-like form that cannot be pumped. Therefore, it is recommended to use this substance at a temperature no lower than $-60^{\circ} \mathrm{C}$. Moreover, at temperatures above $+50^{\circ} \mathrm{C}$, D-limonene oxidizes quickly in the presence of air, so it can be used in processes requiring temperatures below $+50{ }^{\circ} \mathrm{C}[60]$.

\subsection{Silicones}

Silicones are another class of popular low-temperature heat transfer fluids. The most commonly used is polydimethylsiloxane, also referred to as silicone oil [9]. It is a synthetic polymer compound with molecular weight and thermophysical properties dependent on the length of the chain. The temperature range in which it is possible to use silicone oil is very wide, ranging from -100 to $+260^{\circ} \mathrm{C}[35,63]$. This type of fluid is characterized by a long life in closed systems without oxygen access. Moreover, silicone oil is not very toxic and, with the use of appropriate additives, is also odorless, which makes it a nonburdensome medium for the personnel working with it. It exhibits a low surface tension, making it possible to leak at the joints of the wires, although thanks to this, it improves the wetting properties [64]. Silicones are typically more expensive than aromatic and aliphatic hydrocarbon-based fluids. Because of the negligible toxicity of this class of compounds, they are used mainly in the pharmaceutical industry.

\subsection{Monohydroxyl Alcohols and Polyols}

Monohydric alcohol aqueous solutions are also used as HTFs [65]. Methanol is a popular alcohol used in cooling mixtures due to its low cost and can be used down to $-40^{\circ} \mathrm{C}$. Furthermore, it is possible to inhibit the corrosive properties of methanol solutions by adding appropriate substances. The main disadvantage of this solution is its high toxicity. It is classified as being more harmful than ethylene glycol, and therefore water solutions of methanol are used only in installations located outside the building. Moreover, methanol is a flammable liquid that poses a fire risk during use and storage. Ethanol is a less toxic alternative to methanol. However, it is also a flammable liquid, and its price is much higher than that of methanol. However, due to good thermal and transport properties (including low viscosity, nearly isentropic behavior, and not too low working pressure values), it is considered a working medium for organic Rankine cycle (ORC) technology [66]. On a micro-scale, it was successfully tested in a domestic ORC unit [67].

Alkylene glycols, most commonly ethylene and propylene glycol, are often used as components of liquid HTFs [68]. Ethylene glycol (EG) is practically odorless and miscible with water without restrictions [69]. Its aqueous solutions can be used at temperatures down to the $-40{ }^{\circ} \mathrm{C}$, although due to their high viscosity at low temperatures, they are most often used down to $-10^{\circ} \mathrm{C}$. When used as a freezing point depressant, EG concentrations ranging from 30 to $60 \mathrm{vol} \%$ are commonly used [70]. Various types of additives are also applied to prevent corrosion, the formation of deposits, and foaming. Typically, they are used in concentrations of 0.1 to $3 \mathrm{wt} \%$ of EG, which also has very low vapor pressure compared to water. Because of the relatively low vapor pressure, mixtures of EG and water can retain their properties for longer periods compared to mixtures of water and more volatile alcohols. Although EG is effective as an agent to lower the freezing point and increase the boiling point of the coolant, its main disadvantage is its high toxicity. Therefore, it cannot be used in open systems and is not suitable for use in the food and pharmaceutical 
industries. Propylene glycol (PG) is used as a replacement for EG in many formulations of heat transfer fluid to avoid the toxicity associated with EG [71]. PG is so non-toxic that it has been approved as a food additive. The biggest obstacle to the more widespread use of PG as a base fluid in HTF concentrates is its relatively high cost compared to that of EG. Moreover, propylene glycol is more viscous than ethylene glycol. Therefore, similarly to EG, it is most commonly used down to $-10{ }^{\circ} \mathrm{C}$ due to its high viscosity at low temperatures. It is also important that the addition of EG or PG reduces the heat transfer efficiency compared to pure water.

An alternative to glycols is glycerol due to its non-toxicity and easy biodegradability [72]. Aqueous glycerol solutions are commonly used as heat transfer agents having indirect food contact during rapid freezing in the food industry [73]. However, glycerol and its aqueous solutions are characterized by high viscosity at low temperatures $[74,75]$. Figure 4 presents graphs of the relationships of dynamic viscosity of aqueous glycerol solutions on temperature (in the low range) and on the mass concentration of glycerol. Despite the fact that increasing the content of glycerol in the mixture with water causes a decrease in the freezing point, which results in an increase in the possible range of applications as an HTF, on the other hand, it causes a drastic increase in the solution viscosity, especially at the concentration value of $40 \mathrm{wt} \%$ and more, which is an undesirable phenomenon. The properties of glycerol-ethylene glycol-water mixtures were also investigated in terms of their use as HTFs. The solution that contained $40 \mathrm{wt} \%$ water and $60 \mathrm{wt} \%$ of glycerolethylene glycol mixture with a composition of $71.4 \mathrm{wt} \%$ glycol and $28.6 \mathrm{wt} \%$ of glycerol was characterized by the lowest pour point, which equaled $-49.84{ }^{\circ} \mathrm{C}$ [76]. However, the greatest problem with such solutions is the high viscosity.

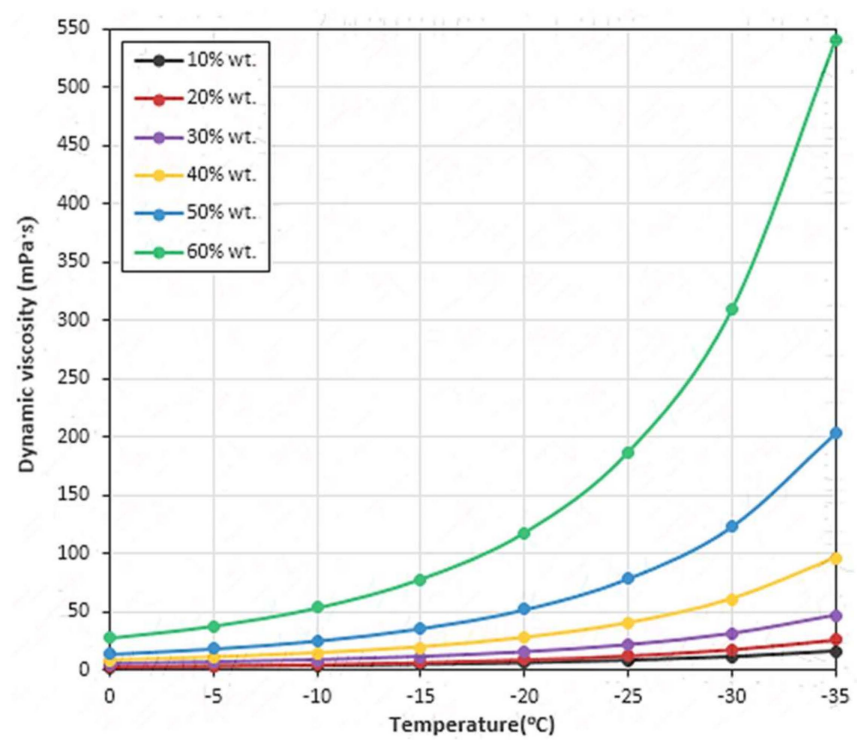

Figure 4. Dynamic viscosity of aqueous glycerol solution profiles versus temperature values depending on the mass concentration of glycerol, based on literature data [77].

\subsection{Summary of Environmental, Technical, and Economic Aspects of Traditional HTFs}

Table 1 summarizes the types of heat and coolant transfer fluids, with a detailed comparison of the environmental, technical, and economic aspects of their application. The environmental aspects were evaluated based on the corrosivity and toxicity characteristics of the fluids. Thermal conductivity, rheological parameters, and Prandtl number were taken into account in assessing technical issues. Economic factors were compared considering the availability and price of the fluids. In the case of conventional HTFs, all of the media presented are highly available, which is their undoubted advantage. 
Table 1. Environmental, technical, and economic aspects comparison of examples of conventional heat transfer fluids.

\begin{tabular}{|c|c|c|c|c|c|c|c|c|c|}
\hline \multirow{2}{*}{ Fluid } & \multicolumn{2}{|c|}{ Environmental Aspects } & \multicolumn{6}{|c|}{ Technical/Efficiency Aspects } & \multirow{2}{*}{$\begin{array}{c}\text { Economic Aspects } \\
\begin{array}{c}\text { Price } \\
(\$ / \mathrm{kg})\end{array}\end{array}$} \\
\hline & Corrosivity & Toxicity & $\begin{array}{c}\text { Temperature Range } \\
\left({ }^{\circ} \mathrm{C}\right)\end{array}$ & $\begin{array}{c}\rho \\
\left(\mathbf{k g} / \mathrm{m}^{3}\right)\end{array}$ & $\begin{array}{c}\mathrm{c} \\
(\mathrm{J} /(\mathrm{kg} \cdot \mathrm{K}))\end{array}$ & $\begin{array}{c}\text { TC } \\
(\mathrm{W} /(\mathrm{m} \cdot \mathrm{K}))\end{array}$ & $\begin{array}{l}\eta \\
(\mathrm{mPa} \cdot \mathrm{s})\end{array}$ & $\begin{array}{l}\operatorname{Pr} \\
(-)\end{array}$ & \\
\hline air & No & No & +540 to 1090 & $\begin{array}{c}1.293\left(0^{\circ} \mathrm{C}\right) \\
1.128\left(40^{\circ} \mathrm{C}\right) \\
1.000\left(80^{\circ} \mathrm{C}\right)\end{array}$ & $\begin{array}{c}1004\left(0^{\circ} \mathrm{C}\right) \\
1004\left(40^{\circ} \mathrm{C}\right) \\
1006\left(80^{\circ} \mathrm{C}\right)\end{array}$ & $\begin{array}{l}0.024\left(0^{\circ} \mathrm{C}\right) \\
0.028\left(40^{\circ} \mathrm{C}\right) \\
0.031\left(80^{\circ} \mathrm{C}\right)\end{array}$ & $\begin{array}{c}0.017\left(0^{\circ} \mathrm{C}\right) \\
0.019\left(40^{\circ} \mathrm{C}\right) \\
0.021\left(80^{\circ} \mathrm{C}\right)\end{array}$ & $\begin{array}{c}0.71\left(0^{\circ} \mathrm{C}\right) \\
0.68\left(40{ }^{\circ} \mathrm{C}\right) \\
0.68\left(80^{\circ} \mathrm{C}\right)\end{array}$ & 0 \\
\hline fluoroalkanes & No & No & -100 to +150 & $\begin{array}{r}1840\left(0^{\circ} \mathrm{C}\right) \\
1800\left(20^{\circ} \mathrm{C}\right)\end{array}$ & $\begin{array}{c}1000\left(0^{\circ} \mathrm{C}\right) \\
1050\left(20^{\circ} \mathrm{C}\right)\end{array}$ & $\begin{array}{c}0.06\left(0^{\circ} \mathrm{C}\right) \\
0.06\left(20^{\circ} \mathrm{C}\right)\end{array}$ & $\begin{array}{c}2\left(0^{\circ} \mathrm{C}\right) \\
1.3\left(20^{\circ} \mathrm{C}\right)\end{array}$ & $\begin{array}{l}33.3\left(0^{\circ} \mathrm{C}\right) \\
22.8\left(20^{\circ} \mathrm{C}\right)\end{array}$ & 5 (TCE) \\
\hline water & Yes & No & 0 to +100 & $\begin{array}{l}1000\left(0^{\circ} \mathrm{C}\right) \\
992\left(40^{\circ} \mathrm{C}\right) \\
972\left(80^{\circ} \mathrm{C}\right)\end{array}$ & $\begin{array}{c}4222\left(0^{\circ} \mathrm{C}\right) \\
4175\left(40^{\circ} \mathrm{C}\right) \\
4195\left(80^{\circ} \mathrm{C}\right)\end{array}$ & $\begin{array}{l}0.558\left(0^{\circ} \mathrm{C}\right) \\
0.633\left(40^{\circ} \mathrm{C}\right) \\
0.673\left(80^{\circ} \mathrm{C}\right)\end{array}$ & $\begin{array}{l}1.792\left(\left(^{\circ} \mathrm{C}\right)\right. \\
0.656\left(40^{\circ} \mathrm{C}\right) \\
0.357\left(80^{\circ} \mathrm{C}\right)\end{array}$ & $\begin{array}{l}13.56\left(0^{\circ} \mathrm{C}\right) \\
4.33\left(40{ }^{\circ} \mathrm{C}\right) \\
2.23\left(80^{\circ} \mathrm{C}\right)\end{array}$ & 0.01 \\
\hline $\begin{array}{c}\text { aliphatic } \\
\text { hydrocarbons }\end{array}$ & Yes & No & -60 to +150 & $815\left(-50^{\circ} \mathrm{C}\right)$ & $1880\left(-50^{\circ} \mathrm{C}\right)$ & $0.115\left(-50^{\circ} \mathrm{C}\right)$ & $15\left(-50^{\circ} \mathrm{C}\right)$ & $245.2\left(-50{ }^{\circ} \mathrm{C}\right)$ & $\begin{array}{c}\text { 2-4 (isoparaffinic } \\
\text { hydrocarbons) }\end{array}$ \\
\hline $\begin{array}{c}\text { aromatic } \\
\text { hydrocarbons }\end{array}$ & Yes & Yes & -70 to +260 & $920\left(-50^{\circ} \mathrm{C}\right)$ & $1636\left(-50^{\circ} \mathrm{C}\right)$ & $0.143\left(-50^{\circ} \mathrm{C}\right)$ & $3.9\left(-50^{\circ} \mathrm{C}\right)$ & $44.6\left(-50^{\circ} \mathrm{C}\right)$ & $\begin{array}{c}2.5-3 \\
\text { (diethylbenzene) }\end{array}$ \\
\hline $\begin{array}{c}\text { ethylene glycol } \\
\text { (41 wt } \% \text { aqueous } \\
\text { solution) }\end{array}$ & Yes & Yes & -20 to +100 & $\begin{array}{c}1069\left(-20^{\circ} \mathrm{C}\right) \\
1062\left(0^{\circ} \mathrm{C}\right)\end{array}$ & $\begin{array}{c}3320\left(-20^{\circ} \mathrm{C}\right) \\
3405\left(0^{\circ} \mathrm{C}\right)\end{array}$ & $\begin{array}{c}0.391\left(-20^{\circ} \mathrm{C}\right) \\
0.406\left(0^{\circ} \mathrm{C}\right)\end{array}$ & $\begin{array}{c}15.6\left(-20^{\circ} \mathrm{C}\right) \\
5.95\left(0^{\circ} \mathrm{C}\right)\end{array}$ & $\begin{array}{c}132.5\left(-20{ }^{\circ} \mathrm{C}\right) \\
49.9\left(0^{\circ} \mathrm{C}\right)\end{array}$ & 1.5 \\
\hline $\begin{array}{l}\text { propylene glycol } \\
\text { (44 wt\% aqueous } \\
\text { solution) }\end{array}$ & Yes & No & -20 to +100 & $\begin{array}{c}1053\left(-20^{\circ} \mathrm{C}\right) \\
1045\left(0^{\circ} \mathrm{C}\right)\end{array}$ & $\begin{array}{c}3620\left(-20^{\circ} \mathrm{C}\right) \\
3640\left(0^{\circ} \mathrm{C}\right)\end{array}$ & $\begin{array}{c}0.362\left(-20^{\circ} \mathrm{C}\right) \\
0.373\left(0^{\circ} \mathrm{C}\right)\end{array}$ & $\begin{array}{l}62\left(-20{ }^{\circ} \mathrm{C}\right) \\
13.9\left(0^{\circ} \mathrm{C}\right)\end{array}$ & $\begin{array}{l}620\left(-20{ }^{\circ} \mathrm{C}\right) \\
135.6\left(0^{\circ} \mathrm{C}\right)\end{array}$ & 3 \\
\hline paraffinic oil & No & No & +30 to +300 & $721\left(300^{\circ} \mathrm{C}\right)$ & $2436\left(300^{\circ} \mathrm{C}\right)$ & $\sim 0.1\left(300{ }^{\circ} \mathrm{C}\right)$ & $1.09\left(300^{\circ} \mathrm{C}\right)$ & $26.6\left(300^{\circ} \mathrm{C}\right)$ & $2-5$ \\
\hline $\begin{array}{l}\text { eutectic mixture of } \\
\text { biphenyl/diphenyl } \\
\text { oxide }\end{array}$ & No & Yes & +12 to +400 & $849\left(300^{\circ} \mathrm{C}\right)$ & $1930\left(300^{\circ} \mathrm{C}\right)$ & $\sim 0.01\left(300^{\circ} \mathrm{C}\right)$ & $0.59\left(300^{\circ} \mathrm{C}\right)$ & $113.9\left(300{ }^{\circ} \mathrm{C}\right)$ & 100 \\
\hline
\end{tabular}


When analyzing the data collected in Table 1, it is clear that the most important and greatest advantages of most traditional HTFs are low toxicity, high availability, and low price, as well as very good thermophysical properties in the temperature range in which they are applied. However, the biggest problem is their high corrosivity. Therefore, when looking for alternative HTFs, researchers should focus on solutions that have a low cost, low toxicity, and are readily available, have comparable or better thermophysical properties, and show significantly lower corrosivity towards the system's construction materials.

\section{Novel HTFs}

\subsection{Nanofluids}

The first and vast group of novel transfer fluids is nanofluids (NFs) with a solid-liquid composition. In this system, nanoparticles (NPs) with an average size below $100 \mathrm{~nm}$, for example, metals, metal oxides or hydroxides, and carbon compounds, are suspended in the base fluid such as water, oil, glycol or a water-glycol mixture, as is shown in Figure 5. An advantage of selecting water-based NFs is their non-toxic nature. Generally, the concentration of nanoparticles in the base fluid does not exceed $10 \%$. The assumption of this technology is the incorporation of solid NPs that possess much higher thermal conductivity (TC) than the base fluid, which therefore can improve the heat transfer coefficient (HTC) [78,79]. Heat transfer improvement of nanofluids may be related to energy transfer by means of nanoparticle dispersion, Brownian motion of particles, particle migration, ballistic phonon motion, reduction in boundary layer thickness, and delay in the boundary layer's development $[27,80,81]$. Iacobazzi et al. [82] investigated the effect of various mechanisms (layering, Brownian motion, clustering, ballistic phonon motion, thermal boundary resistance and mass difference scattering) on the thermal conductivity of NFs. For the first time, the authors suggested the examination of the effect of mass difference scattering. This mechanism was examined because it was the most intensive mechanism reducing the TC value of nanofluids, compared to that of microfluids. In the study, Milanese et al. [83] observed that layering phenomena could be different for metal and metal oxide NPs. In the presence of $\mathrm{Cu}$ NPs, two shell-like formations of water molecule layers were noticed, while for $\mathrm{CuO}$, this phenomenon did not occur. This might explain the higher improvement of TC for $\mathrm{Cu}$-based NF than for CuO NF.

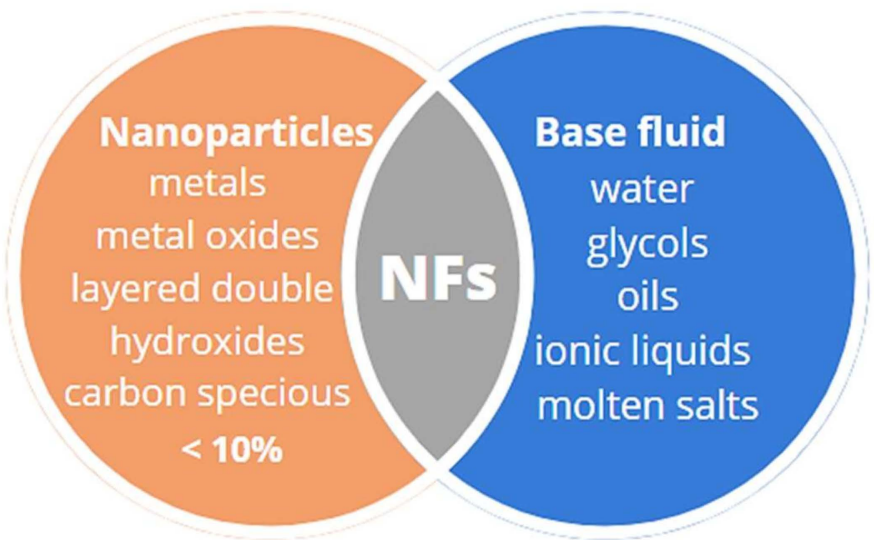

Figure 5. The composition of heat transfer nanofluids.

In the application of nanometric particles, common problems limit the use of fluids with micrometric particle size-the clogging of small passages due to the large agglomeration of the solid fraction may be overcome. However, a crucial aspect is a proper alignment of the nanoparticles' properties with the specific application requirements such as shape, size, thermal stability, chemical composition, and compatibility with the base fluid as well as content in the base fluid. Not only the properties of nanofluids, but also the geometry of heat exchangers may affect thermal performance [84]. For example, Visconti et al. [85] used a modified flat panel solar thermal collector to avoid sedimentation of the solid phase. 
The stability of the NFs is one of the crucial requirements and challenges to be complied with in applications in thermal systems. The prepared suspension should have high stability over a long timeframe. However, the nanofluids may be unstable because of the strong van der Waals interactions and cohesive forces between the nanoparticles. Therefore, the use of appropriate preparation methods is key to its importance. To prevent the agglomeration of nanoparticles in suspension and improve the stability of nanofluids, different methods can be used, particularly $\mathrm{pH}$ control, surfactant incorporation, ultrasonication, surface functionalization or modification, or high-pressure homogenization [29,86-88]. Generally, the addition of the surfactants to the suspension is considered to be the most cost-effective method for obtaining a satisfactory stability of the composition. However, the addition of these substances may have a negative impact on the thermophysical characteristics of NFs [89]. Taking into account the stability, the content of the nanoparticles must be kept at an optimal level. A growth of NPs content causes a higher density of NPs per unit volume. This leads to more frequent particle collisions and a higher possibility of clustering [90]. Typically, the idea is to achieve an improvement in the thermal characteristic but not to increase the fluid viscosity, and hence pumping power requirements along with cost efficiency. To evaluate the stability of NFs, methods such as zeta potential measurement, absorbance spectrometry, and light scattering measurements are commonly implemented [91].

\subsubsection{Metal Oxides}

The first subgroup of nanofluids includes metal oxide nanoparticles. Among them, the most frequently reported are $\mathrm{Al}_{2} \mathrm{O}_{3}, \mathrm{CuO}, \mathrm{ZnO}, \mathrm{SiO}_{2}$, and $\mathrm{TiO}_{2}[92,93]$. Researchers widely implemented these materials because of their relatively low cost and easier production than other NPs. This is beneficial, especially in large-scale production. The advantages of metal oxide NPs compared to metal NPs include resistance to oxidation and chemical stability, and good thermal properties. In addition, several metal oxides have a lower density than metals, which prevent sedimentation when used for nanofluid preparation [93-95].

The addition of metal oxide NPs led to an increase in the heat transfer coefficient compared to the base fluid. Several studies have found that a higher concentration of metal oxide NPs causes a higher thermal conductivity, an increase in Brownian motion, and thermophoresis effects [96]. Thus, the heat transfer coefficient (HTC) increases with the incorporated metal oxide NPs. This suggests that when the NP content in the fluid increases, a greater proportion of its atoms are near the surface, and the surface of the NPs effectively participates in the heat transfer. Moreover, among the factors that affect the heat transfer, the researchers pointed out the synergistic effect of the interaction between metal oxide NPs and fluid, increasing the turbulent flow and improving the cross-sectional gradient of fluid temperature [97]. However, it is important to note that when the optimal content of NPs of metal oxide in the base fluid is exceeded, the HTC value may decrease.

The increase in HTC with the application of NFs instead of the base fluid is correlated with an increase in the effectiveness of the heat exchanger, which led to the reduction in the heat exchanger size to obtain the same heat exchange performance and therefore reduce energy consumption and total costs [98]. Pourfattah et al. [99] observed that the addition of $4 \mathrm{vol} \%$ of $\mathrm{Al}_{2} \mathrm{O}_{3}$ at a Reynolds number of 60,000 causes an augmentation of heat transfer to $22 \%$ as compared to pure water. Manetti et al. [100] concluded that the incorporation of $\mathrm{Al}_{2} \mathrm{O}_{3}$ /water NFs led to a decrease in wall superheating of up to $32 \%$ and $12 \%$ for the smooth and rough surfaces, respectively, compared to pure water, which consequently leads to an improvement in thermal systems' efficiency and safety. Meanwhile, Mansoury et al. [101] compared the effect of nanofluid application in various types of heat exchangers. The authors observed the highest enhancement for the doublepipe heat exchanger (DPHE) with $1 \mathrm{vol} \% \mathrm{Al}_{2} \mathrm{O}_{3}$. A $60 \%$ growth in the Nusselt number was observed in comparison with water, while that for the plate HE was not significant. Yasinskiy et al. [102] investigated the thermal properties of $\mathrm{TiO}_{2}$ nanoparticles suspended in an oil-based mixture of diphenyl oxide and biphenyl with 1-octadecanethiol as a heat 
transfer fluid in CSP. For 2.44 vol\% of the nanoparticles, the thermal characteristics were significantly enhanced, up to $52.7 \%$ for the isobaric specific heat, and up to $25.8 \%$ for the TC. Salimi-Yasar et al. [103] described the application of an oil-based $\mathrm{TiO}_{2}$ nanofluid in a drilling processes as a cutting fluid. All prepared nanofluids had higher $\mathrm{Nu}$ than the base fluid, while the maximum enhancement was $23.7 \%$ for $1 \mathrm{wt} \%$ and a $\operatorname{Re}$ of 900 . The researchers concluded that the application of the oil-based $\mathrm{TiO}_{2}$ nanofluid decreased the operational temperature of the drilling process and improved the heat transfer rate. Ahmed et al. [104] claimed that the application of $\mathrm{ZnO} /$ water NFs in a circular tube heat exchanger led to an improvement in HT of 50\% (1000 to $1500 \mathrm{~W} /\left(\mathrm{m}^{2} \cdot \mathrm{K}\right)$ with the $\operatorname{Re}$ from 5849 to 24,544 ) and a $49 \%$ growth in $\mathrm{Nu}$ number for $0.1 \mathrm{wt} \%$ of $\mathrm{ZnO}$ compared to pure water.

Recent evidence reveals that the use of metal oxide NFs with improved thermal characteristics as a coolant instead of conventional fluids makes it possible to design compact size radiators, and reduce drag and save fuel cost [81,105]. Goudarzi et al. [106] used $\mathrm{Al}_{2} \mathrm{O}_{3} / \mathrm{EG}$ as a cooling transfer fluid in the car radiator. The authors concluded that the Nusselt number and the friction factor for nanofluids were higher than those for pure EG. Eid et al. [107] investigated the heat transfer characteristics of large-surface $\mathrm{TiO}_{2} / \mathrm{EG}$ nanofluid for coolant applications. An improvement in TC of $8.7 \%$ was observed for the application of $0.2 \mathrm{vol} \% \mathrm{TiO}_{2}$. According to experimental and numerical calculations, $0.2 \%$ $\mathrm{TiO}_{2}$ increased the coolant surface heat transfer rate by approximately $24 \%$ compared to pure EG, which could be due to the higher TC value. Krishnakumar et al. [108] prepared the ethylene glycol/water (60:40) nanofluid with the addition of $\mathrm{TiO}_{2}$ nanoparticles. The maximal augmentation in TC was approximately $24 \%$ at $0.8 \mathrm{vol} \%$, while the viscosity increased by approximately $16 \%$. For convection measurements, the greatest enhancement in HTC was $116 \%$ with a Re number of 2050 and $0.5 \mathrm{vol} \%$. Islam et al. [109] characterized the TC of $\mathrm{TiO}_{2} /$ water-EG(50:50) nanofluid as a coolant for proton exchange membrane fuel cells.

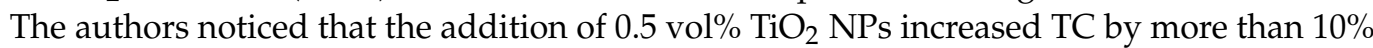
compared to the base fluid. Furthermore, Khan et al. implemented ZnO/water-EG(50:50) as a coolant in a car radiator. With an increasing nanofluid flow rate, HTC also increased. A maximum improvement in heat transfer of up to $36 \%$ was recorded for $0.04 \mathrm{vol} \%$ of $\mathrm{ZnO}$. A higher heat transfer rate was observed at a low flow rate compared to a higher flow rate. However, an extra 2.5\% pumping power was needed for the radiator using $0.04 \%$ $\mathrm{ZnO}$ NP with water-EG(50:50) coolant compared to the base fluid in the same radiator. Meanwhile, Colangelo et al. [110] described the dynamic model to evaluate the efficiency of the heating ventilation air conditioning system working with a water-glycol mixture or an $\mathrm{Al}_{2} \mathrm{O}_{3}$ nanofluid. The model was experimentally validated based on a real plant. The results confirm that the application of nanofluid increases the efficiency by about $10 \%$ and reduces the electrical energy consumption of the system.

An important parameter characterizing metal oxide NFs is the stability of the NP suspensions. High stability and low tendency should describe the prepared nanofluids regarding agglomeration and consequently sedimentation. Iacobazzi et al. [111] characterized the effect of clustering of nanoparticles on thermal conductivity. It was observed that small clusters decreased the TC, while large clusters improved the TC. This phenomenon could be related to NP sedimentation, which causes convective motion generated by particle movement within the fluid under the effect of gravitational force. However, measurements of zeta potential and backscattered light demonstrated that clustering reduces the thermal conductivity of the nanofluid.

In the research performed by Said et al. [98], $\mathrm{CuO} /$ water nanofluid was used in the shell-and-tube heat exchanger. As prepared, the nanofluids were characterized by a zeta potential greater than $\pm 30 \mathrm{mV}$, suggesting that they could maintain their suspension stability. The stability of the suspension depends on the compatibility of its components. Javed et al. [112] recommended the use of a $\mathrm{CuO} /$ waste palm oil nanofluid for heat transfer application. Analysis confirmed that the prepared nanofluids showed excellent stability for at least 6 months with the highest improvement in TC with 0.7 wt.\% of $\mathrm{CuO}$ (enhancement 
of up to $190 \%$ compared to palm oil waste). In some cases, the appropriate solution is the addition of stabilizers to prevent suspension instability. Khanlari et al. [86] applied a water-based $\mathrm{TiO}_{2}$ nanofluid in the plate-type heat exchanger. The $\mathrm{TiO}_{2}$ concentration (size about $14 \mathrm{~nm}$ ) equaling $2 \mathrm{wt} . \%$ increased the heat transfer coefficient to about $6 \%$. Authors concluded that the addition of Triton X-100 surfactant (0.2 wt. \%) prevents sedimentation and flocculation issues, as well as accumulation inside the plate heat exchanger. Another possibility is the idea proposed by Ilyas et al. [88], who analyzed the behavior, thermal, and rheological properties of functionalized $\mathrm{ZnO}$-paraffin oil nanofluids. The $\mathrm{ZnO}$ nanoparticles were functionalized with oleic acid to improve the stability of the suspensions. The authors noticed that the modification of $\mathrm{ZnO}$ was essential to improve the stability of oil-based nanofluids. f-ZnO NFs had a much smaller average particle size than the unmodified ZnO NPs. The highest enhancement in the effective viscosity was about $17 \%$ for $1 \mathrm{wt} \% \mathrm{f}-\mathrm{ZnO}$-oil $\mathrm{NF}$ at $55^{\circ} \mathrm{C}$. The coefficient of thermal expansion was found to be reduced with increasing $\mathrm{f}-\mathrm{ZnO}$ content.

However, the increases in the viscosity, friction factor, and thus pressure drop have become important issues associated with the incorporation of metal oxide NPs. The growth of these parameters is related to higher pumping power requirements and consequently leads to an increase in process cost. Gkountas et al. [113] concluded that for $5 \%$ nanoparticle loading, HTC improvement reached $75 \%$, while the pressure drop increased up to $8 \%$, compared to pure water. Du et al. [114] investigated the application of $\mathrm{CuO} /$ water nanofluid as a heat transfer fluid in geothermal heat exchanger (GHE). The results presented confirm that the incorporation of nanofluid may increase the pumping power consumption of GHE by $16.6 \%$. The ratio between the heat load and the pumping power of the NF increases by $20.2 \%$. Zhong et al. [115] analyzed the heat transfer characteristics of highly self-dispersed $\mathrm{TiO}_{2}$ nanofluid in the multiport minichannel. The addition of $1 \mathrm{vol} \%$ of nanoparticles increased fluid viscosity by about $14.9 \%$ and caused larger friction factors (up to $41.6 \%$ ). Moreover, Wen et al. [116] observed that the addition of ZnO NPs to water resulted in a remarkable increase in viscosity. In addition, the authors noticed that the pressure drop and fanning friction factor of nanofluid were notably higher than those for pure water and increased with nanofluid content. The friction factor increased by $40.9 \%$ for $1.5 \mathrm{vol} \%$, which was mainly caused by the enlarging of the viscosity. However, the thermal performance factor of the $\mathrm{ZnO}$ nanofluid was maintained at about 1 , suggesting that the advantage of heat transfer improvement compensated for the limitation induced by the increase in pressure drop.

The thermal characteristics of metal oxide NFs may also depend on the shape, size, or crystallic form of NPs. Shahrestani et al. [117] noticed that an increase in the volume fraction of nanoparticles may increase the heat transfer coefficient. However, the increase in the diameter of the nanoparticles may decrease the heat transfer coefficient. Authors noticed that an increase in the nanoparticle radius results in a reduced effective thermal conductivity. Innovative research was presented by Zhu et al. [118], who compared the use of $\mathrm{CuO}$ nanospheres and nanowires suspended in water. The diameter of the particles was varied from 30 to $80 \mathrm{~nm}$, while the length was varied from 3.5 to $5.5 \mu \mathrm{m}$, respectively. $\mathrm{CuO}$ nanowires containing nanofluids have a thermal conductivity that is higher than that with nanospheres. The maximum increace in the thermal conductivity of the nanofluid with $\mathrm{CuO}$ nanowires reached up to $60.78 \%$. Ahmadi et al. [119] modeled the heat transfer properties of $\mathrm{CuO}$ suspended in ethylene glycol. Based on the presented results for the analyzed data, it can be concluded that the highest influence on the thermal conductivity ratio of $\mathrm{CuO} / \mathrm{EG}$ fluid is the temperature, followed by the size of the nanoparticles. The least significant parameter was the concentration of $\mathrm{CuO}$. Esfe et al. [120] evaluated the influence of the size of $\mathrm{TiO}_{2}$ nanoparticles $(10-50 \mathrm{~nm}$ ) suspended in water on the convective heat transfer and pressure drop. The highest increase in Nu number was observed for nanoparticles with an average size of about $20 \mathrm{~nm}$ and a concentration of $1.5 \mathrm{vol} \%$. With a higher $\mathrm{TiO}_{2}$ content, a greater pressure drop is seen in the nanofluid. However, when the particle size is reduced, it decreases the pressure drop. This may be explained because in a volume 
fraction, when the size of the nanoparticles decreases, the surface area increases, while in turn the velocity gradient in the fluid has more variation and therefore the pressure drop will increase. The effect of the crystal form of $\mathrm{TiO}_{2}$ in the nanofluid on the heat transfer characteristics in the microchannel for TES was evaluated by Ding et al. [121]. Rutile and anatase forms of $\mathrm{TiO}_{2}$ were compared. The authors found that the rutile-water nanofluid had better stability than the anatase-water nanofluid, and the TC value was higher than for the anatase-water system, with a maximal increase of $3.27 \%$ in comparison with pure water. The viscosity of rutile-water increased by about $4.87 \%$, while that of anatase-water by about $7.45 \%$. For $1 \mathrm{wt} \%$ of the rutile-water nanofluid, Nu increased from $6 \%$ to $41 \%$, while the increase in the pressure drop was maximally $8 \%$.

Milanese et al. [122] investigated the optical behavior of various water-based nanofluids applied in solar power systems. In all experiments, transmittance grew, passing from the visible to the infrared region. It was noted that the application of $0.05 \mathrm{vol} \% \mathrm{TiO}_{2}$, which can completely absorb solar radiation at a depth of $1 \mathrm{~cm}$, led to the minimizing of the pumping and maintenance costs. Moreover, the authors characterized the possibility of application of NPs in the gas-based system [123]. It was observed that the optical properties of $\mathrm{ZnO}, \mathrm{Fe}_{2} \mathrm{O}_{3}$ and $\mathrm{CeO}_{2}$ gas-phase NFs were not affected by the growth in the temperature in the range $25-500{ }^{\circ} \mathrm{C}$. These results confirm that such NPs can operate at very high temperatures. An interesting direction is a solution developed by Potenza et al. [124] with the application of an air-based $\mathrm{CuO} \mathrm{NP}$ working fluid in a parabolic trough collector. The authors pointed out the deposition of NPs within the receiver pipe due to humidity as a critical issue related to the application of this type of HTF.

\subsubsection{Metals}

The next subgroup of nanofluids includes the material based on the addition of metal nanoparticles such as $\mathrm{Cu}, \mathrm{Al}, \mathrm{Fe}, \mathrm{Ni}, \mathrm{Si}, \mathrm{Ag}$, etc., to the base fluid [125]. Metallic species are applied because of their high thermal conductivity coefficient, significantly higher in comparison with their oxides. Nakhchi and Esfahani [126] investigated the possibility of applying a $\mathrm{Cu} /$ water nanofluid in the heat exchanger tube equipped with cross-cut twisted tape. The authors concluded that thermal performance was enhanced by increasing the content of NP inside the duct, increasing up to $46 \%$ for $1.5 \mathrm{vol} \%$ compared to the base fluid. The results show that the HTC increased up to $23.20 \%$ with the increasing NP content from 0 to $1.5 \mathrm{vol} \%$. The researchers explained this fact by the fact that the higher Re improves the greater swirling motion, causing a smaller thermal boundary layer thickness along the channel wall, while collisions between nanoparticles and between nanoparticles and the tube wall lead to higher energy exchange. However, the friction factor of the 0.1 $1.5 \mathrm{vol} \%$ nanofluids was up to 1.33 times higher than that of pure water. Mebarek-Oudina and Bessaïh [127] performed a numerical analysis of natural convection heat transfer of a $\mathrm{Cu}$-water nanofluid in a vertical cylindrical annulus. The researchers observed that with the increase in the NP concentration, the maximum temperature decreases and the heat transfer increases. For the Ra value of $10^{4}$, the average Nu number grew with the increase in the NP content. This was related to the enhancement of the effective TC of the nanofluid as the number of NPs increased. Gholamalipour et al. [128] investigated the usage of a $\mathrm{Cu}$ /water nanofluid inside a porous annulus. In all the Ra and Da numbers, when the NP content increased, the average Nu number increased and reached the highest value at $4 \mathrm{vol} \%$. Furthermore, at $\mathrm{Ra}=104$, the highest effect of nanoparticle addition on enhancing the heat transfer was up to $13 \%$. The positive impact of NP addition on the heat transfer was explicable because the stream functions were compressed near the walls, which led to the velocity increment and improvement of the heat convection process. Saleem et al. [129] compared the heat transfer characteristics of different forms of copper NP (spherical, blades, and platelets) suspended in a water-based nanofluid. The velocity of a fluid drops by aggregation of the solid fraction. The authors noticed that plateletshaped nanoparticles offered the greatest improvement in heat transfer, providing the maximum increase in velocity, viscosity, and temperature compared to the NFs based 
on spherical and blade-shaped nanoparticles. Hadavand et al. [130] studied the coolant properties of a $\mathrm{Ag} /$ water nanofluid in a semi-circular lid-driven cavity. The presence of $\mathrm{Ag}$ nanoparticles at higher concentrations (6 vol\%) in the nanofluid, with the higher TC and enhancement of the Nu number, leads to better temperature distribution with smaller temperature gradients, and thus improved cooling performance of the cavity. Mir et al. [131] investigated the heat transfer performance of $\mathrm{Ag} /$ water nanofluid in an elliptical curved minichannel. The researchers observed that an increase in the number of NPs leads to an increase in the temperature of the central line of flow and an increase in Nu number. The presence of Ag NP in the nanofluid induced the destruction and postponement of the creation of the thermal boundary layer as well as the extension of the collision of NPs with each other and heated surfaces. Furthermore, the higher content of NPs leads to the growth of the local friction factor, which is related to the rise in the viscosity and density of the fluid and, as a result, to the augmentation of shear stress and fluid momentum depreciation. Saleh and Sundar [132] evaluated the heat transfer characteristics of Ni/water NFs in a corrugated plate heat exchanger. At $0.6 \mathrm{vol} \%$ of NPs and $60^{\circ} \mathrm{C}$, the TC and viscosity increased by approximately $33.92 \%$ and $67.45 \%$, respectively, compared to pure water. The addition of nanoparticles augmented the overall HTC, as well as the Nu number, by up to $38.60 \%$ and $42.68 \%$ (for $0.6 \mathrm{vol} \%$ ), while the thermal entropy generation was reduced by $15.70 \%$. However, frictional entropy generation and pumping power increased by $68.29 \%$ and $61.77 \%$. Esfe et al. [133] investigated the thermal conductivity and viscosity of Fe/water nanofluids with different sizes of NPs (37, 71, and $98 \mathrm{~nm}$ ). TC increased as the NP content increased, while the NP size decreased. However, the dynamic viscosity of NF was enhanced with higher concentration and diameter of NPs. Khoshvaght-Aliabadi et al. [134] compared the performance of Ag/water, Fe/water, and $\mathrm{Cu}$ /water NFs in a U-tube heat exchanger with a concentration of $0.1 \mathrm{vol} \% \mathrm{NP}$. The authors observed that the HTC and pressure drop of all metallic nanofluids were higher than those of pure water. Furthermore, the highest values were recorded for $\mathrm{Ag} /$ water NFs, with the highest augmentations of $18.2 \%$ and $8.5 \%$ for HTC and pressure drop, respectively. Research on nanofluids with metal nanoparticles is developing to utilize their magnetic properties and a strong magnetic field to obtain a higher level of heat transfer enhancement. Numerical studies on the application of an external magnetic field to nanofluids have been reported, considering various concentrations of nanoparticles: copper [135] and silver [136] were reported. The experimental analyses are less common, but they are presented in [137] and [138]. From the numerical analysis, there is a conclusion that the strong magnetic field attenuates the convection, so its negative influence was observed. An opposite effect was observed in the experimental studies; the enhancement of heat transfer processes caused by a strong magnetic field was exhibited. The most probable reason for such different results comes from the method of nanofluid treatment, such as using a single-phase medium (typical numerical approach) or a two-phase one.

\subsubsection{Layered Double Hydroxide (LDH)}

One more subgroup is layered double hydroxides (LDH). Generally, this is the class of two-dimensional layered anionic structures. Their significant advantages include their flexible and tunable chemical composition, as well as their high chemical and thermal stability [139]. These compounds mainly include $\mathrm{Fe}, \mathrm{Al}, \mathrm{Ni}, \mathrm{Zn}$, and $\mathrm{Cu}$ hydroxides. Chakraborty et al. [140] investigated the potential application of $\mathrm{Cu}-\mathrm{Al} \mathrm{LDH}$ nanofluid as a coolant in a pressure atomized spray. The authors evaluated the effect of the $\mathrm{Cu}: \mathrm{Al}$ molar ratio on TC, stability, and heat transfer characteristics. All suspensions showed zeta potential values above $\pm 30 \mathrm{mV}$, thus being classified as highly stable. The optimal ratio of Cu:Al was 4:1. NF with $0.016 \%$ NPs achieved the highest improvement in TC with a $15.17 \%$ increase compared to pure water. However, the viscosity values remarkably increased with a higher NP loading, at $0.024 \%$ reaching $57.16 \%$ increase. In another study, Tiara et al. [141] compared the influence of various surfactant additives with $\mathrm{Cu}-\mathrm{Al} \mathrm{LDH}$ applied as a heat transfer fluid in jet impingement on a hot steel surface. The nanofluid with Tween 20 
showed the highest TC improvement and the maximal decrease in surface tension. In addition, viscosity was significantly reduced upon incorporation of Tween 20 surfactant. This nanofluid reached the highest cooling rate of $154^{\circ} \mathrm{C} / \mathrm{s}$ and the critical heat flux (CHF) value of $3.06 \mathrm{MW} / \mathrm{m}^{2}$. Chakraborty et al. [142] applied ternary LDH compounds such as $\mathrm{Cu}-\mathrm{Zn}-\mathrm{Al}(4: 1: 1)$ in spray cooling. In this case, the highest $\mathrm{TC}(0.68 \mathrm{~W} /(\mathrm{m} \cdot \mathrm{K}))$ was obtained for $0.016 \%$ of $\mathrm{LDH}$ and was about $13.9 \%$ higher than pure water. Meanwhile, for $0.024 \%$ the viscosity of the nanofluid was $68.7 \%$ higher than for water. The maximum cooling rate was achieved for $0.016 \%$ and was $158{ }^{\circ} \mathrm{C} / \mathrm{s}(18.5 \%$ higher than pure water), thus suggesting that this value was significantly higher than above the ultra-fast cooling range $\left(>133.3^{\circ} \mathrm{C} / \mathrm{sec}\right.$ for a plate of $\left.6 \mathrm{~mm}\right)$. At $0.016 \%$ of the $\mathrm{LDH}$ content, a $15.6 \%$ reduction in coolant consumption compared to water was achieved. Furthermore, the average HTC value of $2340 \mathrm{~W} /\left(\mathrm{m}^{2} \cdot \mathrm{K}\right)$ was recorded for $0.016 \%$ of $\mathrm{Cu}-\mathrm{Zn}-\mathrm{Al} \mathrm{LDH}$ nanoparticles.

\subsubsection{Carbon Species}

Researchers commonly introduce carbon species into the base fluid to improve the heat transfer characteristics. Among them, graphene, graphene oxide, carbides, MXenes, carbon nanotubes, and many more may be distinguished.

The SiC nanofluid is characterized by relatively low cost, stability, widespread availability, and simple preparation processes [143]. Ponnada et al. [143] applied the SiC/water nanofluid in a circular tube and investigated the effect of volume concentration and NP size. The authors concluded that heat transfer grew with increasing NP content and NP size. The HT augmentation was up to $36.74 \%$ compared to the base fluid. Moreover, the friction factor increased with a higher amount and size of NP. Al-Waeli et al. [144] characterized the application of $\mathrm{SiC} /$ water nanofluid in a photovoltaic thermal system. The authors observed that the addition of $3 \mathrm{wt} \%$ of SiC NPs increased NF density by up to $0.0082 \%$ and viscosity by up to $1.8 \%$, compared to water. Meanwhile, TC was improved by $8.2 \%$ and thermal efficiency increased by $100.19 \%$. The suspension showed high stability and usefulness over a long timeframe; after three months, TC was only reduced by 0.003 $\mathrm{W} /(\mathrm{m} \cdot \mathrm{K})$. Srinivasan et al. [145] compared the thermal characteristics of various base oils (engine, furnace and transformer oils) with the addition of $\mathrm{SiC}$ nanoparticles. For all base oils, the authors observed the highest enhancement of heat capacity for $2 \mathrm{vol} \%$ of $\mathrm{SiC}$. Moreover, the $\mathrm{SiC} /$ engine oil nanofluid showed the highest growth in heat capacity by up to 8.97 times compared to the base fluid.

Important examples of nanofluids also incorporate carbon nanotubes (CNTs). The thermal conductivity of CNTs is variable and depends on the length of the particles and their type (SWCNT and MWCNT). MWCNTs possess very high thermal conductivity, up to $3000 \mathrm{~W} /(\mathrm{m} \cdot \mathrm{K})$ at room temperature [146]. Moradi et al. [147] characterized the flow and heat transfer properties of MWCNT/water nanofluid. The authors observed the highest HTC growth (about 35\%) for the lowest MWCNT NP concentration- $0.04 \mathrm{vol} \%$. Sarafraz et al. [148] investigated the fouling formation and thermal properties of CNT/water nanofluids in a heat sink. The nanofluids presented a higher HTC and lower temperature profile inside the heat sink compared to pure water. The increase in NP mass concentration improved the HTC to a large extent. Fouling thermal resistance is strongly dependent on the NP content, and at a higher NP amount, a shorter operating time is required to reach the constant fouling thermal resistance. Fan et al. [149] characterized the impact of the length and diameter of the MWCNT on the heat transfer performance. The length of the CNT was 1 or $5 \mu \mathrm{m}$, while the diameter was about 30 or $60 \mathrm{~nm}$. The high stability of the samples was observed after four weeks. Critical heat flux grew by about $60 \%$. The authors assumed that CNTs with a length of $5 \mu \mathrm{m}$ and a diameter of $60 \mathrm{~nm}$ presented the highest enhancement in quenching and boiling behaviors. Abdeen et al. [150] evaluated the influence of the carbon nanotube content in the CNT/water nanofluid on the corrosion performance. The CNT nanofluids showed relatively low corrosion rates, comparable to those of tap water and deionized water. The lowest corrosion rate was observed for $0.1 \mathrm{wt} \% \mathrm{CNT}$ nanofluids at room temperature. The inhibitory properties of CNTs at low concentrations were related 
to the physical adsorption of CNTs on the surface of the metal and the formation of a barrier to prevent attack of the metal's surface by the solution ions. However, the inhibition efficiency decreased with increasing CNT concentrations.

Additionally, graphene and graphene oxide NFs were used as a heat transfer fluid. Graphene materials have significant advantages such as high flexibility and thermal conductivity, chemical inertness, and high density [151,152]. The heat transfer characteristics of the graphene nanoplatelet fluid in a microchannel were investigated by Sarafraz et al. [80]. The higher content of NP led to an increase in TC, heat capacity, and density, with the highest improvement being by $27 \%, 16.8 \%$, and $5 \%$, respectively. This heat transfer enhancement was correlated with the thermophoresis effect. The movement of graphene towards the cold environment was related to the temperature gradient and the density variation between the hot and cold regions. Graphene NPs absorb the thermal energy as sensible heat and transport it to the cold environment, causing the heat transfer from the hot surface towards the working fluid. Sözen et al. [153] used a graphene/water NF with $2 \mathrm{wt} \%$ of NPs to improve the thermal performance of air-to-air heat recovery units. The authors concluded that the graphene/water NF was more efficient than pure water, with a maximum thermal efficiency value of $34.1 \%$. The maximum rate of improvement in thermal efficiency was $87.7 \%$. An application of nanofluid minimized the thermal resistance of the heat pipes; thus, the HT grew. The highest reduction in thermal resistance was $52.3 \%$. The use of nanofluid with graphene NPs provided the difference between the average evaporator and condenser temperatures of the heat pipe to reach lower values. Consequently, boiling occurred at lower temperatures. Selvam et al. [151,154] used a graphene/water-EG(70:30) nanofluid as a coolant for the automobile radiator. The authors observed that addition of graphene NP led to an increase in the convective heat transfer coefficient (up to 51\%) and the overall heat transfer coefficient (up to 104\%). Meanwhile, the pressure drop increased with the NP loading.

A novel class of 2D carbon compounds used as a heat transfer fluid is the MXenes. A major example of these is titanium carbide $\left(\mathrm{Ti}_{3} \mathrm{C}_{2} \mathrm{~T}_{\mathrm{x}}\right) \cdot \mathrm{Ti}_{3} \mathrm{C}_{2} \mathrm{~T}_{\mathrm{x}}$ possesses metallic-like and ceramic properties with high thermal and electrical conductivity, and resistance to heat [155]. Bao et al. [156] characterized the TC, stability and viscosity of $\mathrm{Ti}_{3} \mathrm{C}_{2} \mathrm{~T}_{\mathrm{x}} / \mathrm{EG}$. The researchers observed that the nanofluid with $1 \mathrm{vol} \%$ delaminated $\mathrm{Ti}_{3} \mathrm{C}_{2} \mathrm{~T}_{\mathrm{x}}$ presented high stability within 30 days. The TC of NF with 5 vol. $\%$ of delaminated $\mathrm{Ti}_{3} \mathrm{C}_{2} \mathrm{~T}_{\mathrm{x}}$ increased by $64.9 \%$ compared to pure EG. MXene NFs presented Newtonian fluid properties. Aslfattahi et al. [157] investigated the potential of MXene/silicon oil nanofluid application as a heat transfer fluid in the concentrated photovoltaic thermal collector. The $0.1 \mathrm{wt} \%$ MXene/silicon oil nanofluid was found to be thermally stable up to $380^{\circ} \mathrm{C}$. The highest TC improvement of about $64 \%$ was observed for $0.1 \mathrm{wt} \%$ MXene/silicon oil compared to base silicone oil at $150{ }^{\circ} \mathrm{C}$. The viscosity of silicone oil with the addition of Mxene NPs was independent of the content of MXene nanoparticle and was reduced by $32 \%$ when the temperature increased from 25 to $50^{\circ} \mathrm{C}$. Viscosity reduction is a desirable requirement, as this leads to reducing the pumping power in a flow channel. Samylingam et al. [158] used a composition of MXene/palm oil as a heat transfer fluid in the PV/T system. For $0.2 \mathrm{wt} \%$, MXene/palm oil showed a $68.5 \%$ higher TC than pure palm oil at $25^{\circ} \mathrm{C}$, while viscosity reduction reached $61 \%$ when the temperature increased from 25 to $50{ }^{\circ} \mathrm{C}$. The unique feature of MXene NF was the negligible increase in its viscosity with an increase in the NP content. Similar research was performed by Rubbi et al. [159] who applied MXene/soybean oil in the PV/T system. The zeta potential values revealed the physical stability of the NF. The TC of $\mathrm{Ti}_{3} \mathrm{C}_{2} \mathrm{~T}_{\mathrm{x}}$ /soybean oil for $0.125 \mathrm{wt} \%$ of $\mathrm{Ti}_{3} \mathrm{C}_{2} \mathrm{~T}_{\mathrm{x}}$ showed an improvement of $60.82 \%$ at $55{ }^{\circ} \mathrm{C}$, while the specific heat increased by about $24.5 \%$ compared to pure soybean oil. Moreover, the surface temperature decreased by $14^{\circ} \mathrm{C}$ by applying the NF as a cooling fluid. Both studies showed that these NFs had better thermal performance than $\mathrm{Al}_{2} \mathrm{O}_{3}$ /water composition. Samylingam et al. [158] showed that MXene/silicon oil NFs reached an increase in thermal efficiency of about $16 \%$, a flow rate of $0.07 \mathrm{~kg} / \mathrm{s}$, and a growth of $\mathrm{HTC}$ of about $9 \%$ compared to the $\mathrm{Al}_{2} \mathrm{O}_{3}$-water heat transfer fluid. Meanwhile, 
Rubbi et al. [159] reached the highest increase of $14.3 \%$ at $0.06 \mathrm{~kg} / \mathrm{s}$ for MXene/soybean than for alumina/water NF.

\subsubsection{Hybrid Nanofluids}

The application of hybrid nanofluids is one of the solutions to improve the thermal characteristics. Hybrid nanofluids are compositions with at least two different nanoparticles suspended in the base fluid. This method allows higher efficiency to be obtained because of the synergistic effect of NPs on the heat transfer properties. These hybrid nanofluids include, in particular, the combinations of metal-metal, metal oxide-metal oxide, and metal-metal oxide nanoparticles, as well as metal oxide-carbon compounds.

Hassan et al. [160] combined $\mathrm{Cu}$ and $\mathrm{Ag}$ nanoparticles (50:50 $v / v)$ in water and compared the, with a single NF with $\mathrm{Cu}$ and $\mathrm{Ag}$, respectively. The temperature profile of the hybrid nanofluid was improved compared with that of the $\mathrm{Cu}$ /water nanofluid because of its high heat capacity enhancement by the addition of Ag NP. The highest wall shear stress was observed at the wall for Ag/water, while it was reduced when a hybrid nanofluid was prepared. It was concluded that a hybrid NF may develop heat and mass flow and HT rate. Akram et al. [161] performed a theoretical investigation and compared the properties of $\mathrm{Ag} /$ water NF with hybrid $\mathrm{Ag} / \mathrm{Au}$-water NF. The velocity of the hybrid nanofluid was lower than that of the $\mathrm{Ag} /$ water nanofluid. With the addition of Ag NPs to water, an increase of up to $31 \%$ in TC was noticed, while when an equal amount of gold nanoparticles was incorporated into the silver-water nanofluid, the TC increased to $71.53 \%$.

Hayat and Nadeem [162] compared the thermal properties of $\mathrm{CuO} /$ water $\mathrm{NF}$ and hybrid $\mathrm{Ag} / \mathrm{CuO} /$ water NF. The application of hybrid nanofluids (Ag-CuO/water) led to a further increase in the heat transfer rate. $\mathrm{Ag}-\mathrm{CuO} /$ water $\mathrm{NF}$ reduced fluid velocity and reached a higher temperature than a single nanofluid $(\mathrm{CuO}-$ water). The reason was that more massive particles overcome the single NP fluid flow. A major conclusion based on the performed research was that hybridity promotes the temperature distribution and the HT rate at the surface. Ghadikolaei et al. [163] investigated the potential of the combination of $\mathrm{TiO}_{2}$ and $\mathrm{Cu}$ NPs in the water-based nanofluid. The authors evaluated the influence of the NPs shape (brick, cylinders, and platelets) on the thermal properties. The highest temperature occurred for platelet NPs and hybrid $\mathrm{TiO}_{2}-\mathrm{Cu} /$ water nanofluid, compared to $\mathrm{Cu}$ /water NF, and other NPs shapes. The local skin friction coefficient for hybrid nanofluids was lower than that for nanofluids, whereas the value of Nu number for hybrid nanofluids was higher than that for the single nanofluid.

Gürbüz et al. [164] studied the application of hybrid $\mathrm{CuO} / \mathrm{Al}_{2} \mathrm{O}_{3} /$ water NFs in a U-type tubular heat exchanger. The use of hybrid nanofluid led to higher growth in overall HTC compared to $\mathrm{CuO} /$ water NF. The maximum enhancement in HTC of the hot side applying $1 \mathrm{wt} \%$ of $\mathrm{CuO} / \mathrm{Al}_{2} \mathrm{O}_{3}$ NPs achieved $12.9 \%$, while the highest increase in HTC of the cold side was $11.5 \%$. Minea [165] compared the heat transfer characteristics of $\mathrm{Al}_{2} \mathrm{O}_{3} /$ water, $\mathrm{Al}_{2} \mathrm{O}_{3} / \mathrm{SiO}_{2} /$ water, and $\mathrm{Al}_{2} \mathrm{O}_{3} / \mathrm{TiO}_{2} /$ water NFs. The highest $\mathrm{HT}$ enhancement was observed for the composition containing $2.5 \% \mathrm{Al}_{2} \mathrm{O}_{3}$ and $1.5 \%$ of $\mathrm{SiO}_{2}$ (enhanced by 257 and a maximum enhancement of $241 \%$ in the Nusselt number. This was related to the highest viscosity and good TC. However, the application of these NFs caused higher pumping power requirements.

Gupta et al. [166] studied the potential of hybrid metal/COOH-functionalized MWCNT/water NFs. Metal NPs were $\mathrm{Cu}, \mathrm{Zn}, \mathrm{Fe}$, and $\mathrm{Ag}$, respectively. Among all the measured hybrid metal/COOH-MWCNT NFs, $\mathrm{Cu} / \mathrm{COOH}$-functionalized MWCNT/water presented the highest stability and remained stable for more than 45 days without the addition of any stabilizer. This composition had the highest TC with respect to water, with an enhancement of 78.5\%. This was caused by the covalent attachment of $\mathrm{Cu}$ NPs to MWCNT, which promotes strong coupling. In the case of hybrid $\mathrm{Cu} / \mathrm{COOH}-\mathrm{MWCNT} \mathrm{NFs}$, the viscosity did not change significantly with the shear rate; thus, the pumping power would remain constant.

Kumar and Sarkar [167] applied $0.01 \mathrm{vol} \% \mathrm{Al}_{2} \mathrm{O}_{3}-\mathrm{MWCNT} /$ water nanofluid in a minichannel heat sink. The highest improvement in convective HTC of $44.02 \%$ was ob- 
served with MWCNT nanofluid compared to the base fluid. However, the highest pressure drop, increasing by $51.2 \%$ as compared to the base fluid, was recorded for the MWCNT NF. The performance evaluation criteria had a value $>1$ for all nanofluids, suggesting that nanofluids were a more effective coolant compared to pure water, with the greatest value being 1.26 for MWCNT NF. However, the optimal mixing ratio of $\mathrm{Al}_{2} \mathrm{O}_{3}$ and MWCNT was $3: 2$, for which the hybrid nanofluid had the highest HTC to pressure drop ratio.

Hussien et al. [168] evaluated the potential application of a hybrid MWCNT/graphene NPs nanofluid in a mini-tube. Hybrid MWCNT/GNP nanofluids reduced the wall temperature in comparison with pure water and MWCNT nanofluids. The introduction of GNPs into MWCNT/water nanofluids caused an average improvement in HTC of $8.8 \%$. The high ability of hybrid NF to transfer heat was related to the developed contact surface area and improved TC. Maximal enhancement occurred for the hybrid 0.25 MWCNT/0.035 GNP nanofluids at $\operatorname{Re}=200$ with an increase of $43.4 \%$ and a $11 \%$ increase in pressure drop. Meanwhile, Said et al. [169] studied the thermal characteristics of hybrid functionalized carbon nanofibers/reduced graphene oxide NFs. The NPs content was $0.04 \mathrm{vol} \%$ and the hybrid NF presented excellent stability within 6 months. The TC values were highest for the hybrid nanofluids and a maximum thermal conductivity of $0.798 \mathrm{~W} /(\mathrm{m} \cdot \mathrm{K})$ was observed at $55^{\circ} \mathrm{C}$. The viscosity of hybrid NFs was lower than that for $\mathrm{rGO} /$ water and functionalized carbon nanofibers/water monofluids.

\subsection{Supercritical $\mathrm{CO}_{2}$}

The second example of novel HTFs is supercritical carbon dioxide $\left(\mathrm{s}-\mathrm{CO}_{2}\right)$, due to its highly desirable non-flammable, non-explosive, odorless, non-toxic, and non-corrosive nature [170]. Moreover, it is readily available, inexpensive, and stable at high temperature. The operational temperature range is $-73^{\circ} \mathrm{C}$ to $1000{ }^{\circ} \mathrm{C}$ [171]. Carbon dioxide acts as a supercritical fluid above its critical temperature $\left(31.1^{\circ} \mathrm{C}\right)$ and critical pressure $(7.38 \mathrm{MPa})$. This state, when $\mathrm{CO}_{2}$ adopts intermediate properties between liquid and gas (gas with a density like liquid), may easily be reached. An outstanding capacity to withstand very high temperature and excellent thermal features characterize s- $\mathrm{CO}_{2}$, and thus it may be an effective HTF. It is important that in the near-critical region, the density of $\mathrm{s}-\mathrm{CO}_{2}$ for variable pressure does not show substantial growth. The thermo-physical characteristics of s- $\mathrm{CO}_{2}$ are temperature-dependent. Notably, near the pseudocritical temperature, the specific heat approaches its highest value. This shows differences in flow and HT characteristics compared to conventional fluids. The TC of s- $\mathrm{CO}_{2}$ increased with the bulk temperature in the subcritical region, whereas near the critical point, the TC decreases first and approaches the lowest value, and then grows to the highest value before lowering to a flat line. A significant drawback is that near the critical region, there occurs a rapid change in the properties of s- $\mathrm{CO}_{2}$. When the temperature distribution of the $\mathrm{s}-\mathrm{CO}_{2}$ flow reaches pseudocritical temperature, the notable density gradient at a pressure slightly above a critical value (7.6 MPa) generates buoyancy effects [170]. Buoyancy has a prominent influence on heat transfer due to the deformation of the flow velocity profile. Consequently, the heat transfer coefficient decreases. Wang et al. [170] concluded that the buoyancy effects are greater with higher heat flux values. Secondary circulation becomes more visible at higher heat flux levels and increases the temperature variation between the top and bottom tube surfaces. Wang et al. [172] and Zhang et al.[173] confirmed that HTC in the horizontal tube are higher than in the vertical tube, because the disturbance of secondary flow in the horizontal tube overcame the limitations of temperature and velocity boundary layers on convection $\mathrm{HT}$. Many researchers investigated the benefits and limitations of various applications of s- $\mathrm{CO}_{2}$, such as $\mathrm{HTFs}$. s- $\mathrm{CO}_{2}$ has a high potential to eliminate heat exchangers in solar plants, because it can be used simultaneously as an HTF for the solar collector and as the working fluid for the power cycle. This resulted in more efficient and less complex power units [171]. Wang et al. [174] observed that in parabolic trough solar receivers, the non-uniform solar flux distribution can induce significant secondary flow of s- $\mathrm{CO}_{2}$, which improves the synergy of the velocity vector and 
the temperature gradient in the fluid, benefiting the convective heat transfer. Meanwhile, Wang et al. [172] observed that in a helically coiled tube, with increasing heat flux, the HTC decreased in the pseudocritical temperature region, whereas the HTC was almost unchangeable in the liquid-like region. While Guo et al. [175] noticed that in a mini tube, HTC decreased with increasing heat flux and decreasing mass flux, but was minimally affected by pressure because the wall temperature was away from the pseudocritical point. Moreover, under a high heat flux/mass flux ratio, the buoyancy effect was important and reduced the HT. It is an important feature that geothermal systems using $\mathrm{CO}_{2}$ as the working fluid achieve $\mathrm{CO}_{2}$ sequestration in deep reservoirs due to the fluid loss effect. In their research, Zhang et al. [176] described the comparison of supercritical $\mathrm{CO}_{2}$ used in an artificial smooth parallel-plate fracture and a rough and tortuous fracture that mimics rock fracture in geothermal systems. Compared to the smooth parallel-plate fracture, the $\mathrm{CO}_{2}$ flowing through the rough and tortuous fracture extracted less heat from the hot rock. This was related to the less efficient heat exchange caused by the channeling effect. The overall $\mathrm{Nu}$ number was higher in a rough fracture with a larger Re number due to the impact of the disturbance impact on the development of the boundary layer. Khalesi et al. [177] noted that HTC and pressure drop are influenced by the extensive variation of thermophysical characteristics of s- $\mathrm{CO}_{2}$ near the critical point and along the pseudocritical region. The values of friction coefficient and Nu number vary along the channel as a result of the change in the velocity gradient and the wall heat flux. Operating pressure has a great impact on the pressure drop and heat transfer performance of the heat exchanger. Pressure drop and HT performance were remarkably higher for pressures away from the critical point than for pressures near the critical point. However, large variations of $\mathrm{Nu}$ number were not apparent for high operating pressures.

Taking into account the environmental friendliness of $\mathrm{CO}_{2}$ (global warming potential (GWP) index equal to 1) and its safety class A1 (according to the American Society of Heating, Refrigerating and Air-Conditioning Engineers (ASHRAE) standards [178]), $\mathrm{CO}_{2}$ has been recognized as the most promising refrigerant in applications where ammonia cannot be used. Various configurations of s- $\mathrm{CO}_{2}$ refrigeration were examined by Bellos and Tzivanidis [179]. For the evaporator temperature in the range from -35 to $+5{ }^{\circ} \mathrm{C}$, when changing the gas cooler outlet temperature from 35 to $50^{\circ} \mathrm{C}$, the system with the mechanical subcooling system was found to be the most efficient solution.

\subsection{Molten Salts/Molten Salts NFs}

Molten salts (MS) are another representative of novel HTFs. The term molten salt refers to the liquid prepared by melting inorganic salt or a mixture of salts. The mixing of salts led to a reduction in the melting point and simultaneously a steady rise in the high boiling temperature [180]. Typically, the operational temperature of molten salts is in the range of 250 to $1000^{\circ} \mathrm{C}$. Some of the main advantages of MS include good thermal conductivity, high stability, large specific heat capacity, low viscosity, environment friendliness, and low price. However, some of the MS heat transfer fluids possess a high melting point, even above $120{ }^{\circ} \mathrm{C}$; thus, this may limit their application due to the risk of freezing. Another drawback is the high corrosivity of MS towards steel. Liu et al. [181] studied the risk of corrosion for stainless steel and alloys working with different MS HTFs. The authors observed the highest corrosion rate in $\mathrm{NaCl}-\mathrm{KCl}-\mathrm{ZnCl}_{2} \mathrm{MS}$, which was equal to $450 \mu \mathrm{m} /$ year.

The heat transfer process of molten salts combines radiative, conductive, and convective heat transfer and due to the high viscosity, the dominant mode is radiative transfer with absorbing-scattering media [182]. A group of MS includes carbonates, fluorides, nitrides, and chlorides [183]. Usually used MS include Solar Salt $\left(\mathrm{KNO}_{3}-\mathrm{NaNO}_{3}\right)$ and Hitec Salt $\left(\mathrm{KNO}_{3}-\mathrm{NaNO}_{3}-\mathrm{NaNO}_{2}\right)$. Hitec Salt has a lower melting point but also lower stability than Solar Salt. Zou et al. [184] compared the thermophysical properties and thermal stability of Hitec Salt modified by the addition of $\mathrm{CaNO}_{3}$ with pure Hitec Salt and Solar Salt. A low melting point and a high decomposition point occurred for the Hitec salt with $\mathrm{Ca}\left(\mathrm{NO}_{3}\right)_{2}$. The appropriate operating temperature was $200-565{ }^{\circ} \mathrm{C}$, which was higher than that of 
Hitec Salt and Solar Salt. Furthermore, the average specific heat and TC of the Hitec Salt with the $\mathrm{Ca}\left(\mathrm{NO}_{3}\right)_{2}$ additive were nearly $1520 \mathrm{~J} /(\mathrm{kg} \cdot \mathrm{K})$ and $0.655 \mathrm{~W} /(\mathrm{m} \cdot \mathrm{K})$, respectively, and MS presented improved heat transfer performance than Hitec salt and Solar Salt. Meanwhile, Vaka et al. [185] investigated the effect of different salt components, including $\mathrm{NaNO}_{3}, \mathrm{KNO}_{3}, \mathrm{LiNO}_{3}, \mathrm{CsNO}_{3}$, and $\mathrm{Ca}\left(\mathrm{NO}_{3}\right)_{2}$, on the melting point of the MS mixture. The authors observed that the sample with $\mathrm{NaNO}_{3}: 4 \mathrm{wt} \%, \mathrm{KNO}_{3}: 22 \mathrm{wt} \%, \mathrm{LiNO}_{3}: 10.79$ $\mathrm{wt} \%, \mathrm{CsNO}_{3}: 44 \mathrm{wt} \%$, and $\mathrm{Ca}\left(\mathrm{NO}_{3}\right)_{2}: 19.20 \mathrm{wt} \%$ resulted in the lowest melting point of $61.40{ }^{\circ} \mathrm{C}$. The results obtained show that with increasing $\mathrm{KNO}_{3}, \mathrm{LiNO}_{3}$, and $\mathrm{CsNO}_{3}$ in the salt mixture, the melting point decreased. Chen and Zhao [186] investigated the optimal ratio of $\mathrm{Ca}\left(\mathrm{NO}_{3}\right)_{2}, \mathrm{NaNO}_{3}$ and $\mathrm{KNO}_{3}$ in the $\mathrm{MS}$ mixture for heat transfer and energy storage applications. The researchers observed that the composition with a 32:24:44 wt $\%$ ratio for $\mathrm{Ca}\left(\mathrm{NO}_{3}\right)_{2}, \mathrm{NaNO}_{3}$ and $\mathrm{KNO}_{3}$, respectively, had the best thermal performance, with a specific heat capacity of 1700 and $1200 \mathrm{~J} /(\mathrm{kg} \cdot \mathrm{K})$ for the solid phase and liquid phase, respectively. This composition showed a relatively low melting point of about $80^{\circ} \mathrm{C}$, a low viscosity near zero at $200^{\circ} \mathrm{C}$ and thermal conductivity in the range of 1 to $3 \mathrm{~W} /(\mathrm{m} \cdot \mathrm{K})$. $\mathrm{Xu}$ et al. [180] evaluated the potential of $\mathrm{KCl}-\mathrm{MgCl}_{2}$ (molar ratio 32:68) application as a HTFs and TES material. The authors applied the MS at a temperature of up to $800{ }^{\circ} \mathrm{C}$. The specific heat capacity in the liquid state was between $990-1013 \mathrm{~J} /(\mathrm{kg} \cdot \mathrm{K})$, while the TC was between 0.465 and $0.424 \mathrm{~W} /(\mathrm{m} \cdot \mathrm{K})$ at temperatures of $450-800{ }^{\circ} \mathrm{C}$. However, the average melting point was relatively high and equal to about $424^{\circ} \mathrm{C}$. The initial treatment of MS led to the elimination of water and oxygen and contributed to the lower corrosivity. Trablesi et al. [187] compared the use of synthetic oil, therminol and molten salt $\left(\mathrm{NaNO}_{3}\right.$ $\mathrm{KNO}_{3}$ ). In the power plant with MS applied as HTF, the overall energy efficiency increased by about $6 \%$, compared to therminol. Meanwhile, the approximate decrease in cost was about $20 \%$.

In addition, an interesting combination is molten salt nanofluids (MSNFs). As for other nanofluids, the major drawbacks include the increase in viscosity and problems with stability. These NFs offer greater compatibility for corrosion resistance and prevention in steel at higher temperatures. The NPs dispersed in the molten salt encourage the creation of an electrical double layer on the surface of the NPs. Ordinarily, silica or alumina NPs possess a hydroxyl group attached to their surface and thus have a negatively charged surface. The molten salt mixture possesses a positive charge, with different values of the zeta potential. One salt will have a higher zeta potential than the other, and therefore will be more attracted to negatively charged NPs than the other salt and start to assemble around it [188]. Repulsion between the electric double layers considerably reduced the agglomeration between NPs, and consequently, NPs disperse [189]. Xiong et al. [190] used Solar Salt with the addition of $1 \%$ of $\mathrm{SiO}_{2}$ NPs. The TC enhancement was about $52 \%$ for the sample prepared by the high-temperature melting method with 90 min of mixing, compared to the base MS. However, the melting point decreased by about $7{ }^{\circ} \mathrm{C}$ and the specific heat increased by about $46 \%$. Li et al. studied the effect of introduction of $10 \mathrm{wt} \%$ of $\mathrm{SiO}_{2} \mathrm{NPs}$ to Solar Salt on the thermal properties. The researchers observed an increase in TC of up to $54.5 \%$. Furthermore, the authors proved that the improvement of TC may be assigned to the enhanced probability and frequency of ion collision, indicated by the change in potential energy. Ying et al. [191] investigated the heat transfer potential of $\mathrm{Al}_{2} \mathrm{O}_{3}$ /Hitec. For $0.063 \mathrm{wt} \%$ of $\mathrm{Al}_{2} \mathrm{O}_{3} \mathrm{NPs}$, the greatest heat transfer performance was recorded, with an increase in HTC by $7.29 \%$ and Nu number by $6.9 \%$. The authors observed that $\mathrm{Al}_{2} \mathrm{O}_{3} /$ Hitec MSNFs markedly decreased the peak temperature of the outer and inner heated surface of the tube wall. They also concluded that at a low NP content, the specific heat capacity mostly affected the heat transfer. Additionally, Wei et al. [192] proposed the use of Solar Salt with MgO NPs. The NPs content was in the range of 2.5-10 wt\%. The researchers concluded that the optimal amount of NPs was $5 \%$ with an increase in specific heat capacity of $11.9 \%$ and thermal conductivity of up to $62.5 \%$. Meanwhile, they did not observe the remarkable growth in viscosity (up to $0.6 \%$ ). 


\subsection{Ionic Liquids/Ionanofluids}

One of the important groups of novel HTFs is also ionic liquids (ILs). Ionic liquids are salts composed only of ions, which exist in the liquid form at a temperature below $100{ }^{\circ} \mathrm{C}$ [193]. Commonly, they consist of organic cations and organic/inorganic anions. The cations are, e.g., azolium, phosphonium, pyridinium, pyrrolidinium, and alkylammonium. Inorganic anions include, for instance, halides, nitrates, perchlorates, sulfates, and azides. Meanwhile, organic anions may include, for example, benzoates, sulfacetamides, alkylcarbonates, and organic carboxylates [194]. As opposed to molten salts, which usually operate at high temperatures and are highly corrosive and viscous materials, the ILs can be liquids at very low temperatures, as low as $-96^{\circ} \mathrm{C}$, and possess very low viscosity and corrosivity [193]. ILs show a low freezing point, a wide liquid range, non-flammability, high thermal stability, and very low vapor pressure [195]. Wadekar [34] characterized the potential application of [bmim][Tf2N] in a plate heat exchanger, and in a shell-and-tube heat exchanger. The author compared the thermal properties of [bmim][Tf2N] with the Dowtherm. Dowtherm showed the higher HTC and the higher pressure drop than IL. Oster et al. [196] described the thermal properties of trihexyl(tetradecyl)phosphonium acetate $\left([\mathrm{AcO}]^{-}\right)$, butanoate $\left([\mathrm{ButO}]^{-}\right)$, hexanoate $\left([\mathrm{HexO}]^{-}\right)$, octanoate $\left([\mathrm{OctO}]^{-}\right)$, and decanoate $\left([\mathrm{DecO}]^{-}\right)$ILs and their mixtures with water. Density and heat capacity decreased with the growth of the anion chain length, and the authors observed the same trend for IL-water mixtures. The density of pure ILs was lower than the density of water (10-13\%). The TC of ILs decreased to $[\mathrm{P} 14,6,6,6][\mathrm{HexO}]$, while further growth was observed in the alkyl chain length. For water-IL mixtures, the enhancement in TC was between $15.24 \%$ and $18.59 \%$, compared to pure ILs. The author concluded that the major limitation of ILs' application as HTFs is the relatively high price, thus the preparation of water-ILs mixtures may remarkably reduce the costs.

Commonly proposed solutions to improve the thermal characteristics of ionic liquids include the addition of various nanoparticles and the formation of ionanofluids, also called as nanoparticles, which enhance ionic liquids. Paul et al. [197] compared the thermal properties of the ionic liquid [C4mim] [NTf2] and an ionanofluid with $\mathrm{Al}_{2} \mathrm{O}_{3} \mathrm{NPs}$. INFs showed an enormous enhancement of shear viscosity with the addition of a small amount of NP. TC increased with NPs concentration, and the maximum enhancement of up to $11 \%$ occurred for $2.5 \mathrm{wt} \% \mathrm{Al}_{2} \mathrm{O}_{3}$. Furthermore, the heat capacity of INFs increased significantly by up to $62 \%$ with $2.5 \mathrm{wt} \% \mathrm{Al}_{2} \mathrm{O}_{3}$. Hosseinghorbani et al. [198] added graphene oxide to [Bmim][NTf2] as a HTF in a concentrated solar power plant. The authors observed that the graphene oxide INFs presented excellent stability for up to 2 weeks. Thermal conductivity and specific heat capacity grew by $6.5 \%$ and $42 \%$, respectively, at $2 \mathrm{wt} . \%$ of graphene oxide NPs. However, the greatest HTC enhancement of $7.2 \%$ was achieved for $0.5 \mathrm{wt} . \%$ of graphene oxide NPs. In the study presented by Jóźwiak et al. [146], multiwalled carbon nanotubes were introduced to the $[\mathrm{C} 2 \mathrm{C} 1 \mathrm{im}][\mathrm{SCN}]$ and applied as a working fluid in the heat exchanger. The highest improvement in average convective HTC by $48.1 \%$ was recorded for $0.25 \mathrm{wt} \%$ of MWCNT. However, the pressure drop increased by about $55.2 \%$ in comparison to pure ILs. Thus, the application of INFs may require the installation of much more powerful delivery pumps. Despite this, the performance evaluation criteria reached a value above 1. Das et al. [199] incorporated the MXene NPs into an [MMIM][DMP]/water(20:80 v/v) mixture. INFs showed good stability and the highest improvement of TC was observed by $47 \%$ for $0.2 \mathrm{wt} \%$ of NPs. The authors compared the results for MXene/water-INFs with the results for MXene/palm oil and $\mathrm{Al}_{2} \mathrm{O}_{3} /$ water NFs. HTC increased by $12.6 \%$ and $2 \%$ for aqueous INFs compared to $\mathrm{Al}_{2} \mathrm{O}_{3} /$ water and MXene/palm oil, respectively. 


\subsection{Nano- and Micro-Encapsulated Phase Change Materials}

The next group of novel heat transfer materials comprises encapsulated phase change materials (EPCM). These EPCM materials can absorb and release energy during the phase change transition period, charging and discharging processes at a specific fusion temperature [200]. EPCM materials can be applied in the lower, medium, and higher temperature range (even from -20 up to $200^{\circ} \mathrm{C}$ ), depending on the properties of the components [201]. Based on the size of the EPCM, researchers classified them as micro-encapsulated PCM (MEPCM) and nano-encapsulated PCM (NEPCM) with micrometric and nanometric size, respectively. Further reduction in the EPCM size led to an increase in the thermal transportation capacity. Encapsulated PCM includes inorganic-inorganic, organic-organic, and inorganic-organic combinations. In the EPCM construction, the shell seals the PCM core. Examples of cores include paraffin, polyethylene glycol, n-octadecane, gallium, bismuth, $\mathrm{CaCl}_{2}$ hexahydrate, and many more. However, for example, graphene and its derivatives, silica, and polymers, e.g., melamine-formaldehyde resin, polymethyl methacrylate (PMMA), polyurethane (PU), and polystyrene (PS) may comprise the shell. There are many significant advantages related to the application of encapsulated PCM, such as the prevention of PCM leakage, and excellent thermal transport capability because of the increase in the heat transfer surface area. The presence of encapsulated PCM in the base fluid can improve its thermal conductivity [202]. Chananipoor et al. [203] characterized EPCM suspension composed of n-dodecanol as the core and modified PMMA with graphene oxide as the shell in a double pipe heat exchanger. The authors found that in the turbulent tubular flow of the NEPCM suspension in water, the inlet temperature and the mass fraction of the NEPCM have the greatest impact on the heat transfer performance. The experimental results show that the proposed NPCMs with content equal to $14 \%$ could improve heat transfer for thermal systems compared to pure water. Ghalambaz et al. [204] studied the effect of the addition of ECPM to water, with nonadecan as the inner part and polyurethane as the outer layer. Introducing NEPCM led to an increase in heat transfer of $13 \%$. The phase change of the NEPCM caused an increase of up to about $28 \%$ in heat transfer. Nomura et al. [205] described the properties of MEPCM composed of Al-Si microspheres as a core and $\mathrm{Al}_{2} \mathrm{O}_{3}$ as a shell for heat storage and transfer. The heat capacity was about $233 \mathrm{~J} / \mathrm{g}$, and the composite showed outstanding stability up to 300 heating and cooling cycles. Yang et al. [200] characterized the paraffin@graphene MEPCM. The thermal conductivity of MEPCM was up to $0.418 \mathrm{~W} /(\mathrm{m} \cdot \mathrm{K})$, which was 2.34 times higher than paraffin. For the MEPCM with a paraffin core content greater than $99 \%$, the phase change latent heat was $232.4 \mathrm{~J} / \mathrm{g}$, and therefore was higher than for pure paraffin.

\subsection{Summary of Environmental, Technical, and Economic Aspects of Novel HTFs}

Table 2 summarizes the types of novel heat transfer fluids with a detailed comparison of the environmental, technical, and economic aspects of their application. Due to the focus on competing HTFs with respect to conventional HTFs, all the examples presented in Table 2 are widely available. 
Table 2. Environmental, technical, and economic aspects comparison of examples of novel heat transfer fluids.

\begin{tabular}{|c|c|c|c|c|c|c|c|c|c|c|}
\hline \multirow[b]{2}{*}{ Fluid } & \multicolumn{2}{|c|}{ Environmental Aspects } & \multirow[b]{2}{*}{$\begin{array}{c}\text { Temperature } \\
\text { Range } \\
\left({ }^{\circ} \mathrm{C}\right)\end{array}$} & \multicolumn{3}{|c|}{ Technical Aspects } & \multirow[b]{2}{*}{$\underset{(\mathrm{mPa} \cdot \mathrm{s})}{\eta}$} & \multirow[b]{2}{*}{$\begin{array}{l}\operatorname{Pr} \\
(-)\end{array}$} & \multirow{2}{*}{$\begin{array}{c}\text { Economic Aspects } \\
\text { Estimated } \\
\text { Price }(\$ / \mathbf{k g})\end{array}$} & \multirow[b]{2}{*}{ Ref. } \\
\hline & Corrosivity & Toxicity & & $\begin{array}{c}\rho \\
\left(\mathrm{kg} / \mathrm{m}^{3}\right)\end{array}$ & $\underset{(J / k g \cdot K)}{c}$ & $\begin{array}{c}\text { TC } \\
(W / m \cdot K)\end{array}$ & & & & \\
\hline $0.6 \mathrm{vol} \% \mathrm{Ni} /$ water & Yes & No & 0 to +100 & $\begin{array}{l}1045\left(20^{\circ} \mathrm{C}\right) \\
1035\left(50^{\circ} \mathrm{C}\right)\end{array}$ & $\begin{array}{l}4160\left(20^{\circ} \mathrm{C}\right) \\
4158\left(50^{\circ} \mathrm{C}\right)\end{array}$ & $\begin{array}{l}0.72\left(20^{\circ} \mathrm{C}\right) \\
0.84\left(50^{\circ} \mathrm{C}\right)\end{array}$ & $\begin{array}{c}1.5\left(20^{\circ} \mathrm{C}\right) \\
0.85\left(50^{\circ} \mathrm{C}\right)\end{array}$ & $\begin{array}{l}8.67\left(20^{\circ} \mathrm{C}\right) \\
4.21\left(50^{\circ} \mathrm{C}\right)\end{array}$ & 0.13 & [132] \\
\hline $\begin{array}{c}0.04 \text { vol } \% \\
\mathrm{ZnO} / \mathrm{H}_{2} \mathrm{O}-\mathrm{EG}(50: 50 \text { v/v) } \\
\end{array}$ & Yes & Yes & -20 to +100 & $1002\left(60^{\circ} \mathrm{C}\right)$ & $4016\left(60^{\circ} \mathrm{C}\right)$ & $0.708\left(60^{\circ} \mathrm{C}\right)$ & $0.89\left(60^{\circ} \mathrm{C}\right)$ & $5.048\left(60^{\circ} \mathrm{C}\right)$ & 0.76 & [206] \\
\hline $\begin{array}{c}0.16 \% \text { Cu-Al(4:1) } \\
\text { LDH/water }\end{array}$ & Yes & No & 0 to +100 & n.d & n.d & $0.68\left(30^{\circ} \mathrm{C}\right)$ & $1.35\left(30^{\circ} \mathrm{C}\right)$ & n.d & n.d. & [140] \\
\hline $\begin{array}{c}0.1 \mathrm{wt} \% \\
\mathrm{MWCNT} / \mathrm{CuO} / \text { water }\end{array}$ & Yes & No & 0 to +100 & $\begin{array}{l}998.8\left(20^{\circ} \mathrm{C}\right) \\
992.8\left(40{ }^{\circ} \mathrm{C}\right)\end{array}$ & $\begin{array}{l}4178\left(20^{\circ} \mathrm{C}\right) \\
4175\left(40^{\circ} \mathrm{C}\right) \\
\end{array}$ & $\begin{array}{l}0.54\left(20^{\circ} \mathrm{C}\right) \\
0.76\left(40^{\circ} \mathrm{C}\right)\end{array}$ & $\begin{array}{l}1.02\left(20^{\circ} \mathrm{C}\right) \\
0.66\left(40^{\circ} \mathrm{C}\right)\end{array}$ & $\begin{array}{l}7.89\left(20^{\circ} \mathrm{C}\right) \\
3.63\left(40^{\circ} \mathrm{C}\right) \\
\end{array}$ & 0.07 & [207] \\
\hline $\begin{array}{c}0.04 \text { vol } \% \\
\text { f-CNT/rGO/water }\end{array}$ & Yes & No & 0 to +100 & $\begin{array}{l}997.5\left(25^{\circ} \mathrm{C}\right) \\
986.0\left(55^{\circ} \mathrm{C}\right)\end{array}$ & n.d & $\begin{array}{l}0.65\left(25^{\circ} \mathrm{C}\right) \\
0.80\left(55^{\circ} \mathrm{C}\right)\end{array}$ & $\begin{array}{l}1.1\left(25^{\circ} \mathrm{C}\right) \\
0.6\left(55^{\circ} \mathrm{C}\right)\end{array}$ & n.d & n.d. & [169] \\
\hline supercritical $\mathrm{CO}_{2}$ & Yes & No & -73 to +1000 & $\begin{array}{l}800\left(25^{\circ} \mathrm{C}\right) \\
300\left(50^{\circ} \mathrm{C}\right) \\
190\left(100{ }^{\circ} \mathrm{C}\right) \\
p=10 \mathrm{MPa}\end{array}$ & $\begin{array}{c}3000\left(25^{\circ} \mathrm{C}\right) \\
4000\left(50^{\circ} \mathrm{C}\right) \\
1500\left(100^{\circ} \mathrm{C}\right) \\
p=10 \mathrm{MPa}\end{array}$ & $\begin{array}{c}0.085\left(25^{\circ} \mathrm{C}\right) \\
0.04\left(50^{\circ} \mathrm{C}\right) \\
0.03\left(100^{\circ} \mathrm{C}\right) \\
p=10 \mathrm{MPa}\end{array}$ & $\begin{array}{c}0.07\left(25^{\circ} \mathrm{C}\right) \\
0.025\left(50^{\circ} \mathrm{C}\right) \\
0.025\left(100^{\circ} \mathrm{C}\right) \\
p=10 \mathrm{MPa}\end{array}$ & $\begin{array}{c}2.47\left(25^{\circ} \mathrm{C}\right) \\
2.5\left(50^{\circ} \mathrm{C}\right) \\
1.3\left(100^{\circ} \mathrm{C}\right) \\
p=10 \mathrm{MPa}\end{array}$ & n.d. & [174] \\
\hline Solar Salt & Yes & No & +220 to +550 & $\begin{array}{l}1900\left(300^{\circ} \mathrm{C}\right) \\
1775\left(500{ }^{\circ} \mathrm{C}\right)\end{array}$ & $\begin{array}{l}1495\left(300^{\circ} \mathrm{C}\right) \\
1800\left(500{ }^{\circ} \mathrm{C}\right)\end{array}$ & $\begin{array}{c}0.5\left(300^{\circ} \mathrm{C}\right) \\
0.54\left(500{ }^{\circ} \mathrm{C}\right)\end{array}$ & $\begin{array}{r}3.0\left(300^{\circ} \mathrm{C}\right) \\
1.25\left(500{ }^{\circ} \mathrm{C}\right) \\
\end{array}$ & $\begin{array}{l}8.97\left(300^{\circ} \mathrm{C}\right) \\
4.17\left(500^{\circ} \mathrm{C}\right) \\
\end{array}$ & 0.49 & [208] \\
\hline $0.5 \mathrm{wt} \% \mathrm{SiO}_{2} /$ Hitec & Yes & No & +142 to +450 & n.d & $\begin{array}{l}1890\left(200{ }^{\circ} \mathrm{C}\right) \\
2000\left(300^{\circ} \mathrm{C}\right)\end{array}$ & $\begin{array}{l}0.475\left(200^{\circ} \mathrm{C}\right) \\
0.525\left(300^{\circ} \mathrm{C}\right)\end{array}$ & $\begin{array}{l}2.25\left(200^{\circ} \mathrm{C}\right) \\
1.75\left(300^{\circ} \mathrm{C}\right)\end{array}$ & $\begin{array}{l}8.95\left(200^{\circ} \mathrm{C}\right) \\
6.67\left(300^{\circ} \mathrm{C}\right)\end{array}$ & 0.93 & [189] \\
\hline $\begin{array}{c}20 \% \mathrm{n}- \\
\text { dodecanol/PMMA/GO/water }\end{array}$ & No & No & 0 to +100 & $949.4\left(20^{\circ} \mathrm{C}\right)$ & $3650\left(20^{\circ} \mathrm{C}\right)$ & $0.5\left(20^{\circ} \mathrm{C}\right)$ & $2.49\left(20^{\circ} \mathrm{C}\right)$ & $18.18\left(20^{\circ} \mathrm{C}\right)$ & n.d. & [203] \\
\hline $\begin{array}{c}\text { Ionic liquid } \\
\text { ([bmim][Tf2N]) }\end{array}$ & Yes & No & +25 to +200 & $\begin{array}{l}1429\left(25^{\circ} \mathrm{C}\right) \\
1354\left(100^{\circ} \mathrm{C}\right) \\
1254\left(200{ }^{\circ} \mathrm{C}\right)\end{array}$ & $\begin{array}{c}1252\left(25^{\circ} \mathrm{C}\right) \\
1430\left(100^{\circ} \mathrm{C}\right) \\
1667\left(200{ }^{\circ} \mathrm{C}\right)\end{array}$ & $\begin{array}{c}0.1271\left(25^{\circ} \mathrm{C}\right) \\
0.1219\left(100^{\circ} \mathrm{C}\right) \\
0.1149\left(200^{\circ} \mathrm{C}\right)\end{array}$ & $\begin{array}{l}41.0\left(25^{\circ} \mathrm{C}\right) \\
8.1\left(100^{\circ} \mathrm{C}\right) \\
1.5\left(200{ }^{\circ} \mathrm{C}\right)\end{array}$ & $\begin{array}{l}403.87\left(25^{\circ} \mathrm{C}\right) \\
95.02\left(100^{\circ} \mathrm{C}\right) \\
21.76\left(200{ }^{\circ} \mathrm{C}\right)\end{array}$ & n.d. & [34] \\
\hline
\end{tabular}




\section{Application, Advantages, and Limitations of Conventional and Novel HTFs}

The field of HTFs is developing very quickly. This is dictated by the tremendous demand coming from the industry. Nowadays, HTFs find applications in almost every sector of life. Heat transfer fluids are used as intermediate fluids in processes where cooling or heating is required to reach the desired temperature. In some devices with compact size, shape, or weight, conventional heat transfer fluids such as air or water are not efficient enough, and thus the application of novel transfer fluids with improved thermal characteristics is highly recommended. Table 3 summarizes examples of their employment described in the literature. Furthermore, the major advantages and limitations of each HTF have been considered. Almost all listed fluids can be applied in heat exchangers, being a part of various systems and technologies. One of the key technologies for HTFs application is the concentrated solar power system. In this process, HTFs transfer heat from the receiver to the steam generator. Additionally, HTF may be stored in an insulated tank for power generation in case there is no access to sunlight. Typically, the most favorable HTFs for CSP plants due to their high working temperature and good heat capacity are molten salts [16]. Another example describes the use of HTFs in a secondary loop refrigeration system in coolers, freezers, residential air conditioners or mobile air conditioners [209]. In this case, the most promising candidates are nanofluid refrigerants or encapsulated PCM. For instance, the HTFs are applicable in the cooling of advanced electronic components. Due to the minimal size of electronic devices, a high heat dissipating rate is required [84]. Currently, the most developed group of HTFs in this sector is nanofluids. Furthermore, HTFs may be successfully used to recover heat from a low-temperature exhaust in an organic Rankine cycle. The HTF receives heat from an exhaust source. Subsequently, a second working fluid is vaporized, which flows through a turbine to generate electricity. In this case, nanofluids were also proposed in many studies [210]. Furthermore, an important sector in the use of HTFs is geothermal systems. Nowadays, supercritical $\mathrm{CO}_{2}$ has replaced water as a HTF in these systems [211]. In another paper, the application of methanol, ethanol, and propylene glycol was proposed [212].

Table 3. Examples of various heat and coolant transfer fluids applications.

\begin{tabular}{|c|c|c|c|c|c|c|c|}
\hline Fluid & & Applications & & Advantages & & Limitations & Ref. \\
\hline air & $\begin{array}{l}- \\
-\end{array}$ & $\begin{array}{l}\text { Thermal energy } \\
\text { storage } \\
\text { Photovoltaic } \\
\text { systems }\end{array}$ & $\begin{array}{l}- \\
- \\
-\end{array}$ & $\begin{array}{l}\text { Freely available } \\
\text { Environmental } \\
\text { friendly } \\
\text { Non-vulnerable to } \\
\text { freezing and boiling }\end{array}$ & - & $\begin{array}{l}\text { Lower thermal } \\
\text { conductivity and } \\
\text { volumetric heat } \\
\text { capacity }\end{array}$ & {$[41,46,47]$} \\
\hline water & $\begin{array}{l}- \\
-\end{array}$ & $\begin{array}{l}\text { Parabolic trough } \\
\text { collectors } \\
\text { Thermal energy } \\
\text { storage }\end{array}$ & $\begin{array}{l}- \\
- \\
- \\
-\end{array}$ & $\begin{array}{l}\text { Low cost } \\
\text { High specific heat } \\
\text { Non-toxicity } \\
\text { Low viscosity }\end{array}$ & - & $\begin{array}{l}\text { Corrosive nature } \\
\text { Freezing below } 0{ }^{\circ} \mathrm{C}\end{array}$ & {$[56,213]$} \\
\hline nanofluids & $\begin{array}{l}- \\
- \\
- \\
- \\
- \\
- \\
- \\
-\end{array}$ & $\begin{array}{l}\text { Electronic devices } \\
\text { Solar collectors } \\
\text { Car radiators } \\
\text { Spray cooling } \\
\text { Engines cooling } \\
\text { Chilled water air } \\
\text { conditioning } \\
\text { Refrigeration } \\
\text { systems } \\
\text { Jet impingement } \\
\text { cooling }\end{array}$ & $\begin{array}{l}- \\
-\end{array}$ & $\begin{array}{l}\text { Higher thermal } \\
\text { conductivity and } \\
\text { heat capacity } \\
\text { Various choice of } \\
\text { base fluids and } \\
\text { nanoparticles }\end{array}$ & $\begin{array}{l}- \\
- \\
-\end{array}$ & $\begin{array}{l}\text { Problems with } \\
\text { stability } \\
\text { Possible fouling } \\
\text { effect } \\
\text { Higher viscosity } \\
\text { and pressure drop }\end{array}$ & {$[104,130,154,206,214-218]$} \\
\hline
\end{tabular}


Table 3. Cont.

\begin{tabular}{|c|c|c|c|c|c|c|c|}
\hline Fluid & & Applications & & Advantages & & Limitations & Ref. \\
\hline supercritical $\mathrm{CO}_{2}$ & $\begin{array}{l}- \\
- \\
- \\
-\end{array}$ & $\begin{array}{l}\text { Solar collectors } \\
\text { Thermal energy } \\
\text { storage } \\
\text { District heating } \\
\text { Rankine and } \\
\text { Brayton cycles } \\
\text { Concentrated Solar } \\
\text { Power Plants }\end{array}$ & $\begin{array}{l}- \\
- \\
- \\
-\end{array}$ & $\begin{array}{l}\text { Inexpensive } \\
\text { Non-flammable } \\
\text { Non toxic } \\
\text { Easier to compress } \\
\text { than steam } \\
\text { Less corrosive than } \\
\text { steam } \\
\text { Operational } \\
\text { temperature range } \\
\text { from }-73 \text { to } 1000^{\circ} \mathrm{C}\end{array}$ & - & $\begin{array}{l}\text { Higher initial } \\
\text { capital investments } \\
\text { Dramatic decrease } \\
\text { in density limits the } \\
\text { capability to be } \\
\text { applied as a storage } \\
\text { medium }\end{array}$ & {$[113,176,219-221]$} \\
\hline molten salts & $\begin{array}{l}- \\
-\end{array}$ & $\begin{array}{l}\text { Concentrated solar } \\
\text { power plants } \\
\text { Thermal energy } \\
\text { storage } \\
\text { Jet impingement } \\
\text { cooling }\end{array}$ & $\begin{array}{l}- \\
- \\
-\end{array}$ & $\begin{array}{l}\text { High operation } \\
\text { temperatures } \\
\text { Good thermal } \\
\text { conductivity } \\
\text { High stability } \\
\text { Large specific heat } \\
\text { capacity }\end{array}$ & - & $\begin{array}{l}\text { Freezing at high } \\
\text { temperatures } \\
\text { High corrosivity }\end{array}$ & {$[185,222-225]$} \\
\hline EPCM & - & $\begin{array}{l}\text { Photovoltaic } \\
\text { systems } \\
\text { Thermal energy } \\
\text { storage } \\
\text { Air conditioning } \\
\text { Domestic heat } \\
\text { pump } \\
\text { Electronic devices }\end{array}$ & $\begin{array}{l}- \\
- \\
- \\
- \\
-\end{array}$ & $\begin{array}{l}\text { High thermal } \\
\text { conductivity } \\
\text { Long-term chemical } \\
\text { stability } \\
\text { Non-toxicity } \\
\text { Non-flammable } \\
\text { Non-corrosive }\end{array}$ & - & $\begin{array}{l}\text { Phase segregation } \\
\text { and supercooling } \\
\text { High cost of } \\
\text { encapsulation }\end{array}$ & [201,203,226-228] \\
\hline ionic liquids & - & $\begin{array}{l}\text { Refrigeration } \\
\text { systems } \\
\text { Solar collectors } \\
\text { Concentrated Solar } \\
\text { Power Plants }\end{array}$ & $\begin{array}{l}- \\
- \\
-\end{array}$ & $\begin{array}{l}\text { Thermal stability } \\
\text { Non-volatility and } \\
\text { explosion safety } \\
\text { Ionic conductivity } \\
\text { High heat capacity }\end{array}$ & - & $\begin{array}{l}\text { High cost } \\
\text { Corrosivity }\end{array}$ & {$[198,199,229]$} \\
\hline
\end{tabular}

Table 4 contains the percentage change in the thermophysical and physicochemical properties of selected nanofluids compared to the base fluids. First of all, the addition of nanoparticles to the base fluid does not result in either narrowing or extending the temperature range of the HTF operation, both in the case of water-based and EG/waterbased nanofluids. Moreover, the presence of NPs has a weak effect on physicochemical properties, such as density and specific heat. However, a significant influence on the viscosity is observed, as in the case of water-based nanofluids, it is usually much higher as compared to the base fluid (up to $150 \%$ higher for $20 \%$ n-dodecanol/PMMA/GO/water $\mathrm{NF}$ ). However, the addition of NPs to the EG/water mixture reduces the dynamic viscosity. Otherwise, the presence of NPs affects the thermophysical properties, as a significant increase in the thermal conductivity is observed. This means that nanofluids are better heat conductors than pure base fluids. The change in the demonstrated physicochemical and thermophysical properties results in a change in the value of the Prandtl number. Water-based NFs usually have an increased number of Pr in relation to pure water, while in the case of EG/water-based NFs, a decrease in the value of the Pr number is observed. 
Table 4. Percentage change in thermophysical and physicochemical properties of selected nanofluids compared to the base fluid.

\begin{tabular}{|c|c|c|c|c|c|c|}
\hline \multirow[b]{2}{*}{ Fluid } & \multirow[b]{2}{*}{$\begin{array}{c}\text { Temperature Range } \\
\left({ }^{\circ} \mathrm{C}\right)\end{array}$} & \multicolumn{5}{|c|}{ Percentage Change in Parameter Compared to the Base Fluid } \\
\hline & & $\begin{array}{c}\rho \\
\left(\mathrm{kg} / \mathrm{m}^{3}\right)\end{array}$ & $\begin{array}{c}\mathrm{c} \\
(\mathrm{J} / \mathrm{kg} \cdot \mathrm{K})\end{array}$ & $\begin{array}{c}\text { TC } \\
(W / \mathrm{m} \cdot \mathrm{K})\end{array}$ & $\begin{array}{c}\eta \\
(\mathrm{mPa} \cdot \mathrm{s})\end{array}$ & $\begin{array}{l}\operatorname{Pr} \\
(-)\end{array}$ \\
\hline \multicolumn{7}{|c|}{ Water-based nanofluids } \\
\hline $0.6 \mathrm{vol} \% \mathrm{Ni} /$ water & 0 to +100 & $\begin{array}{l}+4.7 \%\left(20^{\circ} \mathrm{C}\right) \\
+4.8 \%\left(50{ }^{\circ} \mathrm{C}\right)\end{array}$ & $\begin{array}{l}-0.47 \%\left(20^{\circ} \mathrm{C}\right) \\
-0.47 \%\left(50^{\circ} \mathrm{C}\right)\end{array}$ & $\begin{array}{l}+20.6 \%\left(20^{\circ} \mathrm{C}\right) \\
+29.8 \%\left(50{ }^{\circ} \mathrm{C}\right)\end{array}$ & $\begin{array}{l}+49.3 \%\left(20^{\circ} \mathrm{C}\right) \\
+54.8 \%\left(50{ }^{\circ} \mathrm{C}\right)\end{array}$ & $\begin{array}{l}+23.2 \%\left(20^{\circ} \mathrm{C}\right) \\
+18.6 \%\left(50^{\circ} \mathrm{C}\right)\end{array}$ \\
\hline $0.16 \% \mathrm{Cu}-\mathrm{Al}(4: 1) \mathrm{LDH} /$ water & 0 to +100 & n.d. & n.d. & $+10.6 \%\left(30^{\circ} \mathrm{C}\right)$ & $+68.6 \%\left(30^{\circ} \mathrm{C}\right)$ & n.d. \\
\hline 0.05 vol $\%$ graphene/water & 0 to +100 & $\begin{array}{l}+0.05 \%\left(20^{\circ} \mathrm{C}\right) \\
+0.3 \%\left(45^{\circ} \mathrm{C}\right)\end{array}$ & $\begin{array}{l}-2.9 \%\left(20^{\circ} \mathrm{C}\right) \\
-2.4 \%\left(45^{\circ} \mathrm{C}\right)\end{array}$ & $\begin{array}{l}+13.1 \%\left(20^{\circ} \mathrm{C}\right) \\
+21.9 \%\left(45^{\circ} \mathrm{C}\right)\end{array}$ & $\begin{array}{l}+11.4 \%\left(20^{\circ} \mathrm{C}\right) \\
+19.4 \%\left(45^{\circ} \mathrm{C}\right)\end{array}$ & $\begin{array}{l}-4.3 \%\left(20^{\circ} \mathrm{C}\right) \\
-4.6 \%\left(45^{\circ} \mathrm{C}\right)\end{array}$ \\
\hline $\begin{array}{c}0.1 w^{\circ} \% \\
\text { MWCNT/CuO/water }\end{array}$ & 0 to +100 & $\begin{array}{l}+0.08 \%\left(20^{\circ} \mathrm{C}\right) \\
+0.08 \%\left(40^{\circ} \mathrm{C}\right)\end{array}$ & $\begin{array}{c}-0.05 \%\left(20^{\circ} \mathrm{C}\right) \\
0 \%\left(40^{\circ} \mathrm{C}\right)\end{array}$ & $\begin{array}{r}-9.5 \%\left(20^{\circ} \mathrm{C}\right) \\
+20.1 \%\left(40{ }^{\circ} \mathrm{C}\right)\end{array}$ & $\begin{array}{l}+1.5 \%\left(20^{\circ} \mathrm{C}\right) \\
+0.6 \%\left(40^{\circ} \mathrm{C}\right)\end{array}$ & $\begin{array}{l}+12.1 \%\left(20^{\circ} \mathrm{C}\right) \\
-16.2 \%\left(40^{\circ} \mathrm{C}\right)\end{array}$ \\
\hline $\begin{array}{c}0.04 \text { vol } \% \\
\text { f-CNT/rGO/water }\end{array}$ & 0 to +100 & $\begin{array}{l}+0.05 \%\left(25^{\circ} \mathrm{C}\right) \\
+0.05 \%\left(55^{\circ} \mathrm{C}\right)\end{array}$ & n.d. & $\begin{array}{r}+7.3 \%\left(25^{\circ} \mathrm{C}\right) \\
+22.5 \%\left(55^{\circ} \mathrm{C}\right)\end{array}$ & $\begin{array}{l}+22.2 \%\left(25^{\circ} \mathrm{C}\right) \\
+17.9 \%\left(55^{\circ} \mathrm{C}\right)\end{array}$ & n.d. \\
\hline $\begin{array}{c}20 \% \mathrm{n}- \\
\text { dodecanol/PMMA/GO/water }\end{array}$ & 0 to +100 & $-4.9 \%\left(20^{\circ} \mathrm{C}\right)$ & $-12.7 \%\left(20^{\circ} \mathrm{C}\right)$ & $-16.2 \%\left(20^{\circ} \mathrm{C}\right)$ & $+147.8 \%\left(20^{\circ} \mathrm{C}\right)$ & $+158.2 \%\left(20^{\circ} \mathrm{C}\right)$ \\
\hline \multicolumn{7}{|c|}{ Water-EG-based nanofluids } \\
\hline $\begin{array}{c}0.04 \text { vol } \% \\
\mathrm{ZnO} / \mathrm{H}_{2} \mathrm{O}-\mathrm{EG}(50: 50 \mathrm{v} / \mathrm{v})\end{array}$ & -20 to +100 & $-8.4 \%\left(20^{\circ} \mathrm{C}\right)$ & $+14.9 \%\left(20^{\circ} \mathrm{C}\right)$ & $+68.2 \%\left(20^{\circ} \mathrm{C}\right)$ & $-88.8 \%\left(20^{\circ} \mathrm{C}\right)$ & $-92.4 \%\left(20^{\circ} \mathrm{C}\right)$ \\
\hline
\end{tabular}

\section{Conclusions and Future Recommendations}

In this review, major groups of HTFs were described considering their classification as conventional or novel materials. State-of-the-art analysis led to the conclusion that conventional fluids are being displaced by novel materials, mainly nanofluids.

Currently, NFs are the most rapidly developing and expanding group of HTFs. Their beneficial features include the wide range of base fluids and incorporated nanoparticles, which leads to a tunable composition depending on the purpose. From the economic and environmental points of view, the most favorable NFs are water-based NFs. Even with the introduction of higher-priced NPs such as graphene, CNT, or MXene, adding them in such a small amount will not remarkably increase the costs. Generally, the cost of NFs depends on the price of the base fluid. The application of hybrid NFs with synergistic effect is a suitable solution, taking into account the economic point of view and the efficiency of the processes. However, the main limitation with respect to the application of waterbased NFs is the fact that they will operate satisfactorily up to $100{ }^{\circ} \mathrm{C}$. Moreover, it is important to properly select the content of NPs, because too high an amount will lead to the agglomeration and sedimentation and, therefore, will limit the long-term use of NFs. Important aspects that should be further investigated and developed may be the use of surfactants or functionalization of NPs as one way to prevent the destabilization of the suspension. Proper methods should be proposed considering the types of nanoparticles as well as characteristics of base fluids. Table 5 summarizes the most important advantages and disadvantages of nanofluids in terms of environmental, technical, and economic aspects.

Table 5. Summary of advantages and disadvantages of nanofluids in terms of environmental, technical and economic aspects.

Approach Advantages Disadvantages

Most of the currently proposed NFs are non-toxic.
The use of NFs based on nanoparticles does not eliminate the problem of corrosivity of HTFs. 
Table 5. Cont.

\begin{tabular}{|c|c|c|}
\hline Approach & Advantages & Disadvantages \\
\hline Technical & $\begin{array}{l}\text { NFs do not have a narrower } \\
\text { operating temperature range. } \\
\text { NFs are better heat } \\
\text { conductors than base fluids, } \\
\text { as the addition of NPs results } \\
\text { in an increase in TC. }\end{array}$ & $\begin{array}{l}\text { NFs do not have a wider } \\
\text { operating temperature range. } \\
\text { Very often NFs have higher } \\
\text { dynamic viscosity compared } \\
\text { to base fluids, which is a } \\
\text { problem from the installation } \\
\text { point of view. } \\
\text { Too higher amount of NPs } \\
\text { will lead to the agglomeration } \\
\text { and sedimentation, and } \\
\text { therefore limits long-term use } \\
\text { of NFs. }\end{array}$ \\
\hline Economical & $\begin{array}{l}\text { There are a wide range of base } \\
\text { fluids and incorporated } \\
\text { nanoparticles, and thus led to } \\
\text { get a tunable composition } \\
\text { depending on the purpose. } \\
\text { Even with the introducing of } \\
\text { higher-priced NPs, adding } \\
\text { them in such a small amount } \\
\text { will not remarkably rise the } \\
\text { costs. } \\
\text { There are many low-cost } \\
\text { solutions. }\end{array}$ & $\begin{array}{l}\text { Some NFs, despite more } \\
\text { favorable physicochemical } \\
\text { and thermophysical } \\
\text { properties, are too expensive } \\
\text { to be implemented. }\end{array}$ \\
\hline
\end{tabular}

Ultra-low and ultra-high temperature applications require the utilization of materials that are thermally stable and able to operate in such harsh conditions. Here, the solution may be the use of molten salts or supercritical $\mathrm{CO}_{2}$. The main advantages of supercritical $\mathrm{CO}_{2}$ utilization are their non-toxic and non-corrosive nature, and wide operational range. In contrast, molten salts are highly corrosive materials.

Author Contributions: Conceptualization, A.G., N.C., A.R.; formal analysis, A.G., N.C., A.R., J.W.; writing—original draft preparation, A.G., N.C., J.S., J.W.; writing—review and editing, A.G., N.C., J.W.; supervision, A.R.; project administration, A.R.; funding acquisition, A.R. All authors have read and agreed to the published version of the manuscript.

Funding: This research received no external funding.

Institutional Review Board Statement: Not applicable.

Informed Consent Statement: Not applicable.

Data Availability Statement: Data available in a publicly accessible repository as well as in a publicly accessible repository that does not issue DOIs. All data referred to in this paper are accessible according to the list of references.

Acknowledgments: This manuscript was prepared within a scope of a Baltic smart asset management (BSAM) project, co-financed by the Interreg South Baltic Program 2014-2020.

Conflicts of Interest: The authors declare no conflict of interest. 


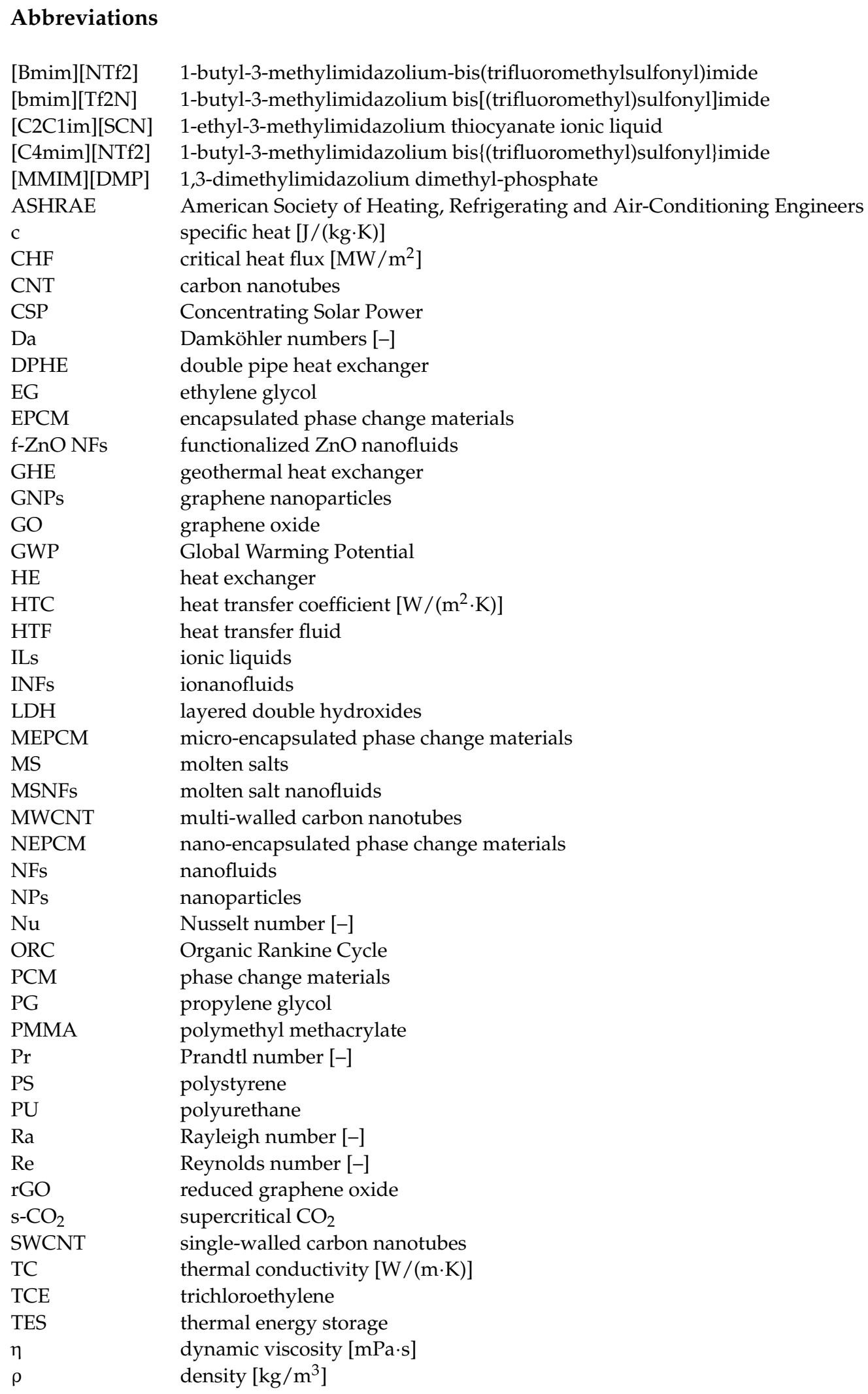

\section{References}

1. Heller, L. Literature Review on Heat Transfer Fluids and Thermal Energy Storage Systems in CSP Plants; STERG: Stellenbosch, South Africa, 2013.

2. Gong, J.; Sumathy, K. Active Solar Water Heating Systems; Elsevier Ltd.: Amsterdam, The Netherlands, 2016 ; ISBN 9780081003022. 
3. Asadi, A. A guideline towards easing the decision-making process in selecting an effective nanofluid as a heat transfer fluid. Energy Convers. Manag. 2018, 175, 1-10. [CrossRef]

4. Kraichnan, R.H. Turbulent thermal convection at arbitrary prandtl number. Phys. Fluids 1962, 5, 1374-1389. [CrossRef]

5. Chernikova, E.A.; Glukhov, L.M.; Krasovskiy, V.G.; Kustov, L.M.; Vorobyeva, M.G.; Koroteev, A.A. Ionic liquids as heat transfer fluids: Comparison with known systems, possible applications, advantages and disadvantages. Russ. Chem. Rev. 2015, 84, 875-890. [CrossRef]

6. Mohapatra, S.C. Heat Transfer Fluids. In Encyclopedia of Chemical Processing; Lee, S., Ed.; Taylor \& Francis: New York, NY, USA, 2006; pp. 1211-1220.

7. Pacio, J.; Wetzel, T. Assessment of liquid metal technology status and research paths for their use as efficient heat transfer fluids in solar central receiver systems. Sol. Energy 2013, 93, 11-22. [CrossRef]

8. Cordaro, J.G.; Rubin, N.C.; Bradshaw, R.W. Multicomponent molten salt mixtures based on nitrate/nitrite anions. J. Sol. Energy Eng. Trans. ASME 2011, 133, 1-5. [CrossRef]

9. Mohapatra, S.C.; Loikits, D. Advances in liquid coolant technologies for electronics cooling. In Proceedings of the Semiconductor Thermal Measurement and Management IEEE Twenty First Annual IEEE Symposium, San Jose, CA, USA, 15-17 March 2005; pp. 354-360. [CrossRef]

10. Minea, A.A. Overview of Ionic Liquids as Candidates for New Heat Transfer Fluids. Int. J. Thermophys. 2020, 41, 1-15. [CrossRef]

11. Krishna, Y.; Faizal, M.; Saidur, R.; Ng, K.C.; Aslfattahi, N. State-of-the-art heat transfer fluids for parabolic trough collector. Int. J. Heat Mass Transf. 2020, 152, 119541. [CrossRef]

12. Malviya, R.; Agrawal, A.; Baredar, P.V. A comprehensive review of different heat transfer working fluids for solar thermal parabolic trough concentrator. Mater. Today Proc. 2020. [CrossRef]

13. Srivastva, U.; Malhotra, R.K.; Kaushik, S.C. Review of heat transport properties of solar heat transfer fluids. J. Therm. Anal. Calorim. 2017, 130, 605-621. [CrossRef]

14. Rajendran, D.R.; Ganapathy Sundaram, E.; Jawahar, P.; Sivakumar, V.; Mahian, O.; Bellos, E. Review on influencing parameters in the performance of concentrated solar power collector based on materials, heat transfer fluids and design. J. Therm. Anal. Calorim. 2020, 140, 33-51. [CrossRef]

15. Benoit, H.; Spreafico, L.; Gauthier, D.; Flamant, G. Review of heat transfer fluids in tube-receivers used in concentrating solar thermal systems: Properties and heat transfer coefficients. Renew. Sustain. Energy Rev. 2016, 55, 298-315. [CrossRef]

16. Vignarooban, K.; Xu, X.; Arvay, A.; Hsu, K.; Kannan, A.M. Heat transfer fluids for concentrating solar power systems-A review. Appl. Energy 2015, 146, 383-396. [CrossRef]

17. Bonk, A.; Sau, S.; Uranga, N.; Hernaiz, M.; Bauer, T. Advanced heat transfer fluids for direct molten salt line-focusing CSP plants. Prog. Energy Combust. Sci. 2018, 67, 69-87. [CrossRef]

18. Hoffmann, J.F.; Vaitilingom, G.; Henry, J.F.; Chirtoc, M.; Olives, R.; Goetz, V.; Py, X. Temperature dependence of thermophysical and rheological properties of seven vegetable oils in view of their use as heat transfer fluids in concentrated solar plants. Sol. Energy Mater. Sol. Cells 2018, 178, 129-138. [CrossRef]

19. Das, S.K.; Choi, S.U.S.; Patel, H.E. Heat transfer in nanofluids-A review. Heat Transf. Eng. 2006, 27, 3-19. [CrossRef]

20. Trisaksri, V.; Wongwises, S. Critical review of heat transfer characteristics of nanofluids. Renew. Sustain. Energy Rev. 2007, 11, 512-523. [CrossRef]

21. Kakaç, S.; Pramuanjaroenkij, A. Review of convective heat transfer enhancement with nanofluids. Int. J. Heat Mass Transf. 2009, 52, 3187-3196. [CrossRef]

22. Sarkar, J.; Ghosh, P.; Adil, A. A review on hybrid nanofluids: Recent research, development and applications. Renew. Sustain. Energy Rev. 2015, 43, 164-177. [CrossRef]

23. Nkurikiyimfura, I.; Wang, Y.; Pan, Z. Heat transfer enhancement by magnetic nanofluids-A review. Renew. Sustain. Energy Rev. 2013, 21, 548-561. [CrossRef]

24. Huminic, G.; Huminic, A. Application of nanofluids in heat exchangers: A review. Renew. Sustain. Energy Rev. 2012, 16, 5625-5638. [CrossRef]

25. Ahmadi, M.H.; Mirlohi, A.; Alhuyi Nazari, M.; Ghasempour, R. A review of thermal conductivity of various nanofluids. J. Mol. Liq. 2018, 265, 181-188. [CrossRef]

26. Yang, L.; Ji, W.; Huang, J.N.; Xu, G. An updated review on the influential parameters on thermal conductivity of nano-fluids. J. Mol. Liq. 2019, 296. [CrossRef]

27. Pinto, R.V.; Fiorelli, F.A.S. Review of the mechanisms responsible for heat transfer enhancement using nanofluids. Appl. Therm. Eng. 2016, 108, 720-739. [CrossRef]

28. Mohammed, H.A.; Bhaskaran, G.; Shuaib, N.H.; Saidur, R. Heat transfer and fluid flow characteristics in microchannels heat exchanger using nanofluids: A review. Renew. Sustain. Energy Rev. 2011, 15, 1502-1512. [CrossRef]

29. Sundar, L.S.; Sharma, K.V.; Singh, M.K.; Sousa, A.C.M. Hybrid nanofluids preparation, thermal properties, heat transfer and friction factor-A review. Renew. Sustain. Energy Rev. 2017, 68, 185-198. [CrossRef]

30. Huminic, G.; Huminic, A. Heat transfer and flow characteristics of conventional fluids and nanofluids in curved tubes: A review. Renew. Sustain. Energy Rev. 2016, 58, 1327-1347. [CrossRef]

31. Paul, T.C.; Tikadar, A.; Mahamud, R.; Salman, A.S.; Morshed, A.K.M.M.; Khan, J.A. A Critical Review on the Development of Ionic Liquids-Based Nanofluids as Heat Transfer Fluids for Solar Thermal Energy. Processes 2021, 9, 858. [CrossRef] 
32. Minea, A.A.; Sohel Murshed, S.M. Ionic liquids-based nanocolloids-A review of progress and prospects in convective heat transfer applications. Nanomaterials 2021, 11, 39. [CrossRef] [PubMed]

33. Liu, J.; Wang, F.; Zhang, L.; Fang, X.; Zhang, Z. Thermodynamic properties and thermal stability of ionic liquid-based nanofluids containing graphene as advanced heat transfer fluids for medium-to-high-temperature applications. Renew. Energy 2014, 63, 519-523. [CrossRef]

34. Wadekar, V.V. Ionic liquids as heat transfer fluids-An assessment using industrial exchanger geometries. Appl. Therm. Eng. 2017, 111, 1581-1587. [CrossRef]

35. Looser, R.; Vivar, M.; Everett, V. Spectral characterisation and long-term performance analysis of various commercial Heat Transfer Fluids (HTF) as Direct-Absorption Filters for CPV-T beam-splitting applications. Appl. Energy 2014, 113, $1496-1511$. [CrossRef]

36. López-González, D.; Valverde, J.L.; Sánchez, P.; Sanchez-Silva, L. Characterization of different heat transfer fluids and degradation study by using a pilot plant device operating at real conditions. Energy 2013, 54, 240-250. [CrossRef]

37. Oyekunle, L.O.; Susu, A.A. Characteristic properties of a locally produced paraffinic oil and its suitability as a heat-transfer fluid. Pet. Sci. Technol. 2005, 23, 1499-1509. [CrossRef]

38. Bradshaw, R.W.; Cordaro, J.G.; Siegel, N.P. Molten Nitrate Salt Development for Thermal Energy Storage in Parabolic Trough Solar Power Systems. In Proceedings of the ASME 2009 3rd International Conference on Energy Sustainability, San Francisco, CA, USA, 19-23 July 2009; Volume 2, pp. 615-624. [CrossRef]

39. Chen, W.; Zou, C.; Li, X. An investigation into the thermophysical and optical properties of SiC/ionic liquid nanofluid for direct absorption solar collector. Sol. Energy Mater. Sol. Cells 2017, 163, 157-163. [CrossRef]

40. Blake, D.M.; Jane, M.; Price, H.; Kearney, D.; Herrmann, U. New Heat Transfer and Storage Fluids for Parabolic Trough Solar Thermal Electric Plants. In Proceedings of the 11th SolarPACES International Symposium on Concentrating Solar Power and Chemical Energy Technologies, Zurich, Switzerland, 4-6 September 2002; pp. 4-8.

41. Good, P.; Zanganeh, G.; Ambrosetti, G.; Barbato, M.C.; Pedretti, A.; Steinfeld, A. Towards a commercial parabolic trough CSP system using air as heat transfer fluid. Energy Procedia 2014, 49, 381-385. [CrossRef]

42. Li, Q.; Bai, F.; Yang, B.; Wang, Y.; Xu, L.; Chang, Z.; Wang, Z.; El Hefni, B.; Yang, Z.; Kubo, S.; et al. Dynamic simulations of a honeycomb ceramic thermal energy storage in a solar thermal power plant using air as the heat transfer fluid. Appl. Therm. Eng. 2018, 129, 636-645. [CrossRef]

43. Liu, M.; Belusko, M.; Steven Tay, N.H.; Bruno, F. Impact of the heat transfer fluid in a flat plate phase change thermal storage unit for concentrated solar power plants. Sol. Energy 2014, 101, 220-231. [CrossRef]

44. Zunft, S.; Hänel, M.; Krüger, M.; Dreißigacker, V.; Göhring, F.; Wahl, E. Jlich solar power tower-experimental evaluation of the storage subsystem and performance calculation. J. Sol. Energy Eng. Trans. ASME 2011, 133, 1-5. [CrossRef]

45. Good, P.; Ambrosetti, G.; Pedretti, A.; Steinfeld, A. A 1.2 MWth solar parabolic trough system based on air as heat transfer fluid at $500{ }^{\circ} \mathrm{C}$-Engineering design, modelling, construction, and testing. Sol. Energy 2016, 139, 398-411. [CrossRef]

46. Cinocca, A.; Cipollone, R.; Carapellucci, R.; Iampieri, V.; Rivo, M. CSP-PT gas plant using air as Heat Transfer Fluid with a packed-bed storage section. Energy Procedia 2018, 148, 852-859. [CrossRef]

47. Toro, C.; Rocco, M.V.; Colombo, E. Exergy and thermoeconomic analyses of central receiver concentrated solar plants using air as heat transfer fluid. Energies 2016, 9, 885. [CrossRef]

48. Orbey, H.; Sandler, S.I. Equation of State Modeling of Refrigerant Mixtures. Ind. Eng. Chem. Res. 1995, 34, 2520-2525. [CrossRef]

49. Smith, G.F. Trichlorethylene: A Review. Occup. Environ. Med. 1966, 23, 249-262. [CrossRef]

50. Cao, W.; Huang, W.; Jiang, F. Numerical study on variable thermophysical properties of heat transfer fluid affecting EGS heat extraction. Int. J. Heat Mass Transf. 2016, 92, 1205-1217. [CrossRef]

51. Modi, A.; Haglind, F. Performance analysis of a Kalina cycle for a central receiver solar thermal power plant with direct steam generation. Appl. Therm. Eng. 2014, 65, 201-208. [CrossRef]

52. Birnbaum, J.; Feldhoff, J.F.; Fichtner, M.; Hirsch, T.; Jöcker, M.; Pitz-Paal, R.; Zimmermann, G. Steam temperature stability in a direct steam generation solar power plant. Sol. Energy 2011, 85, 660-668. [CrossRef]

53. Grigoraş, C.G.; Muntianu, G.; Gavrilă, L. Mathematical modelling of $\mathrm{CaCl}_{2}$ aqueous solutions thermophysical properties. Sci. Study Res. Chem. Chem. Eng. Biotechnol. Food Ind. 2016, 17, 417-426.

54. N'Tsoukpoe, K.E.; Rammelberg, H.U.; Lele, A.F.; Korhammer, K.; Watts, B.A.; Schmidt, T.; Ruck, W.K.L. A review on the use of calcium chloride in applied thermal engineering. Appl. Therm. Eng. 2015, 75, 513-531. [CrossRef]

55. Montes, M.J.; Abánades, A.; Martínez-Val, J.M. Thermofluidynamic model and comparative analysis of parabolic trough collectors using oil, water/steam, or molten salt as heat transfer fluids. J. Sol. Energy Eng. Trans. ASME 2010, 132, 0210011-0210017. [CrossRef]

56. Edwards, J.; Bindra, H. An experimental study on storing thermal energy in packed beds with saturated steam as heat transfer fluid. Sol. Energy 2017, 157, 456-461. [CrossRef]

57. Valkenburg, M.E.V.; Vaughn, R.L.; Williams, M.; Wilkes, J.S. Thermochemistry of ionic liquid heat-transfer fluids. Thermochim. Acta 2005, 425, 181-188. [CrossRef]

58. Merrouni, A.A.; Ouali, H.A.L.; Moussaoui, M.A.; Mezrhab, A. Analysis and comparaison of different Heat Transfer Fluids for a 1MWe Parabolic Trough Collector. In Proceedings of the 2016 International Conference on Electrical and Information Technologies (ICEIT), Tangiers, Morocco, 4-7 May 2016; pp. 510-515. [CrossRef] 
59. Chang, Y.S.; Kim, M.S.; Ro, S.T. Performance and heat transfer characteristics of hydrocarbon refrigerants in a heat pump system. Int. J. Refrig. 2000, 23, 232-242. [CrossRef]

60. Heilig, M.L. United States Patent Office. ACM SIGGRAPH Comput. Graph. 1994, 28, 131-134. [CrossRef]

61. Sun, J. D-limonene: Safety and clinical applications. Altern. Med. Rev. 2007, 12, 259-264.

62. Kim, Y.W.; Kim, M.J.; Chung, B.Y.; Bang, D.Y.; Lim, S.K.; Choi, S.M.; Lim, D.S.; Cho, M.C.; Yoon, K.; Kim, H.S.; et al. Safety evaluation and risk assessment of D-limonene. J. Toxicol. Environ. Heal. Part B Crit. Rev. 2013, 16, 17-38. [CrossRef] [PubMed]

63. Tao, P.; Shu, L.; Zhang, J.; Lee, C.; Ye, Q.; Guo, H.; Deng, T. Silicone oil-based solar-thermal fluids dispersed with PDMS-modified $\mathrm{Fe}_{3} \mathrm{O}_{4} @$ graphene hybrid nanoparticles. Prog. Nat. Sci. Mater. Int. 2018, 28, 554-562. [CrossRef]

64. Sarkar, J.; Bhattacharyya, S. Application of graphene and graphene-based materials in clean energy-related devices Minghui. Arch. Thermodyn. 2012, 33, 23-40. [CrossRef]

65. Anyanwu, E.E. Review of solid adsorption solar refrigerator I: An overview of the refrigeration cycle. Energy Convers. Manag. 2003, 44, 301-312. [CrossRef]

66. Mastrullo, R.; Mauro, A.W.; Revellin, R.; Viscito, L. Flow boiling heat transfer and pressure drop of pure ethanol (99.8\%) in a horizontal stainless steel tube at low reduced pressures. Appl. Therm. Eng. 2018, 145, 251-263. [CrossRef]

67. Wajs, J.; Mikielewicz, D.; Jakubowska, B. Performance of the domestic micro ORC equipped with the shell-and-tube condenser with minichannels. Energy 2018, 157, 853-861. [CrossRef]

68. Colangelo, G.; Favale, E.; Miglietta, P.; De Risi, A. Innovation in flat solar thermal collectors: A review of the last ten years experimental results. Renew. Sustain. Energy Rev. 2016, 57, 1141-1159. [CrossRef]

69. Hayduk, W.; Malik, V.K. Density, Viscosity, and Carbon Dioxide Solubility and Diffusivity in Aqueous Ethylene Glycol Solutions. J. Chem. Eng. Data 1971, 16, 143-146. [CrossRef]

70. Cordray, D.R.; Kaplan, L.R.; Woyciesjes, P.M.; Kozak, T.F. Solid-liquid phase diagram for ethylene glycol + water. Fluid Phase Equilib. 1996, 117, 146-152. [CrossRef]

71. Duell, A.K.; Pankow, J.F.; Gillette, S.M.; Peyton, D.H. Boiling points of the propylene glycol + glycerol system at 1 atmosphere pressure: 188.6-292 ${ }^{\circ} \mathrm{C}$ without and with added water or nicotine. Chem. Eng. Commun. 2018, 205, 1691-1700. [CrossRef] [PubMed]

72. Morrison, L.R. Glycerol. Kirk-Othmer Encycl. Chem. Technol. 2000, 11. [CrossRef]

73. Colorado, D.; Ali, M.E.; García-Valladares, O.; Hernández, J.A. Heat transfer using a correlation by neural network for natural convection from vertical helical coil in oil and glycerol/water solution. Energy 2011, 36, 854-863. [CrossRef]

74. Segur, J.B.; Oderstar, H.E. Viscosity of Glycerol and Its Aqueous Solutions. Ind. Eng. Chem. 1951, 43, 2117-2120. [CrossRef]

75. Takamura, K.; Fischer, H.; Morrow, N.R. Physical properties of aqueous glycerol solutions. J. Pet. Sci. Eng. 2012, 98-99, 50-60. [CrossRef]

76. Spangler, J.A.; Davies, E.C.H. Freezing Points, Densities, and Refractive Indexes of the System Glycerol-Ethylene Glycol-Water. Ind. Eng. Chem. Anal. Ed. 1943, 15, 96-99. [CrossRef]

77. Trejo González, J.A.; Longinotti, M.P.; Corti, H.R. The viscosity of glycerol-water mixtures including the supercooled region. J. Chem. Eng. Data 2011, 56, 1397-1406. [CrossRef]

78. Hafeez, M.U.; Hayat, T.; Alsaedi, A.; Khan, M.I. Numerical simulation for electrical conducting rotating flow of Au (Gold)-Zn (Zinc)/EG (Ethylene glycol) hybrid nanofluid. Int. Commun. Heat Mass Transf. 2021, 124, 105234. [CrossRef]

79. Rashid, U.; Liang, H.; Ahmad, H.; Abbas, M.; Iqbal, A.; Hamed, Y.S. Study of $\left(\mathrm{Ag}\right.$ and $\left.\mathrm{TiO}_{2}\right) /$ water nanoparticles shape effect on heat transfer and hybrid nanofluid flow toward stretching shrinking horizontal cylinder. Results Phys. 2021, 21, 103812. [CrossRef]

80. Sarafraz, M.M.; Yang, B.; Pourmehran, O.; Arjomandi, M.; Ghomashchi, R. Fluid and heat transfer characteristics of aqueous graphene nanoplatelet (GNP) nanofluid in a microchannel. Int. Commun. Heat Mass Transf. 2019, 107, 24-33. [CrossRef]

81. Choi, T.J.; Park, M.S.; Kim, S.H.; Jang, S.P. Experimental Study on the Effect of Nanoparticle Migration on the Convective Heat Transfer Coefficient of EG/Water-based Al2O3 Nanofluids. Int. J. Heat Mass Transf. 2021, 169, 120903. [CrossRef]

82. Iacobazzi, F.; Milanese, M.; Colangelo, G.; Lomascolo, M.; Risi, A. De An explanation of the $\mathrm{Al}_{2} \mathrm{O}_{3}$ nano-fluid thermal conductivity based on the phonon theory of liquid. Energy 2016, 116, 786-794. [CrossRef]

83. Milanese, M.; Iacobazzi, F.; Colangelo, G.; Risi, A. De International Journal of Heat and Mass Transfer An investigation of layering phenomenon at the liquid-Solid interface in $\mathrm{Cu}$ and $\mathrm{CuO}$ based nanofluids. Int. J. Heat Mass Transf. 2016, 103, 564-571. [CrossRef]

84. Colangelo, G.; Favale, E.; Milanese, M.; De Risi, A.; Laforgia, D. Cooling of electronic devices: Nanofluids contribution. Appl. Therm. Eng. 2017, 127, 421-435. [CrossRef]

85. Measurement and control system for thermo- solar plant and performance comparison between traditional and nanofluid solar thermal collectors. Int. J. Smart Sens. Intell. Syst. 2017, 9. [CrossRef]

86. Khanlari, A.; Sözen, A.; Variyenli, H.İ. Simulation and experimental analysis of heat transfer characteristics in the plate type heat exchangers using TiO2/water nanofluid. Int. J. Numer. Methods Heat Fluid Flow 2019, 29, 1343-1362. [CrossRef]

87. Chakraborty, S.; Sengupta, I.; Sarkar, I.; Pal, S.K.; Chakraborty, S. Effect of surfactant on thermo-physical properties and spray cooling heat transfer performance of Cu-Zn-Al LDH nanofluid. Appl. Clay Sci. 2019, 168, 43-55. [CrossRef]

88. Ilyas, S.U.; Narahari, M.; Theng, J.T.Y.; Pendyala, R. Experimental evaluation of dispersion behavior, rheology and thermal analysis of functionalized zinc oxide-paraffin oil nanofluids. J. Mol. Liq. 2019, 294, 111613. [CrossRef] 
89. Zayed, M.E.; Zhao, J.; Du, Y.; Kabeel, A.E.; Shalaby, S.M. Factors affecting the thermal performance of the flat plate solar collector using nanofluids: A review. Sol. Energy 2019, 182, 382-396. [CrossRef]

90. Sharaf, O.Z.; Taylor, R.A.; Abu-Nada, E. On the colloidal and chemical stability of solar nanofluids: From nanoscale interactions to recent advances. Phys. Rep. 2020, 867, 1-84. [CrossRef]

91. Qamar, A.; Anwar, Z.; Ali, H.; Shaukat, R.; Imran, S.; Arshad, A.; Ali, H.M.; Korakianitis, T. Preparation and dispersion stability of aqueous metal oxide nanofluids for potential heat transfer applications: A review of experimental studies. J. Therm. Anal. Calorim. 2020, 1-24. [CrossRef]

92. Noori, T.; Ghangrekar, M.M.; Mitra, A.; Mukherjee, C.K. Conference Proceedings of the Second International Conference on Recent Advances in Bioenergy Research; Springer: Berlin/Heidelberg, Germany, 2018; pp. 285-294. [CrossRef]

93. Said, Z.; Saidur, R. Thermophysical Properties of Metal Oxides Nanofluids. Nanofluid Heat Mass Transf. Eng. Probl. 2017. [CrossRef]

94. Saidina, D.S.; Abdullah, M.Z.; Hussin, M. Metal oxide nanofluids in electronic cooling: A review. J. Mater. Sci. Mater. Electron. 2020, 31, 4381-4398. [CrossRef]

95. Hekmatipour, F.; Jalali, M. Application of copper oxide-thermal oil (CuO-HTO) nanofluid on convective heat transfer enhancement in inclined circular tube. J. Therm. Anal. Calorim. 2019, 136, 2449-2459. [CrossRef]

96. Li, Z.; Sarafraz, M.M.; Mazinani, A.; Hayat, T.; Alsulami, H.; Goodarzi, M. Pool boiling heat transfer to CuO-H $\mathrm{H}_{2} \mathrm{O}$ nanofluid on finned surfaces. Int. J. Heat Mass Transf. 2020, 156, 119780. [CrossRef]

97. Maddah, H.; Ghazvini, M.; Ahmadi, M.H. Predicting the efficiency of CuO/water nanofluid in heat pipe heat exchanger using neural network. Int. Commun. Heat Mass Transf. 2019, 104, 33-40. [CrossRef]

98. Said, Z.; Rahman, S.M.A.; El Haj Assad, M.; Alami, A.H. Heat transfer enhancement and life cycle analysis of a Shell-and-Tube Heat Exchanger using stable $\mathrm{CuO} /$ water nanofluid. Sustain. Energy Technol. Assessments 2019, 31, 306-317. [CrossRef]

99. Pourfattah, F.; Motamedian, M.; Sheikhzadeh, G.; Toghraie, D.; Ali Akbari, O. The numerical investigation of angle of attack of inclined rectangular rib on the turbulent heat transfer of Water- $\mathrm{Al}_{2} \mathrm{O}_{3}$ nanofluid in a tube. Int. J. Mech. Sci. 2017, 131-132, 1106-1116. [CrossRef]

100. Manetti, L.L.; Stephen, M.T.; Beck, P.A.; Cardoso, E.M. Evaluation of the heat transfer enhancement during pool boiling using low concentrations of $\mathrm{Al}_{2} \mathrm{O}_{3}$-water based nanofluid. Exp. Therm. Fluid Sci. 2017, 87, 191-200. [CrossRef]

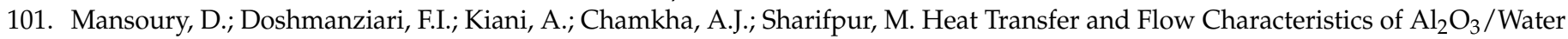
Nanofluid in Various Heat Exchangers: Experiments on Counter Flow. Heat Transf. Eng. 2020, 41, 220-234. [CrossRef]

102. Yasinskiy, A.; Navas, J.; Aguilar, T.; Alcántara, R.; Gallardo, J.J.; Sánchez-Coronilla, A.; Martín, E.I.; De Los Santos, D.; FernándezLorenzo, C. Dramatically enhanced thermal properties for $\mathrm{TiO}_{2}$-based nanofluids for being used as heat transfer fluids in concentrating solar power plants. Renew. Energy 2018, 119, 809-819. [CrossRef]

103. Salimi-Yasar, H.; Zeinali Heris, S.; Shanbedi, M. Influence of soluble oil-based $\mathrm{TiO}_{2}$ nanofluid on heat transfer performance of cutting fluid. Tribol. Int. 2017, 112, 147-154. [CrossRef]

104. Ahmed, W.; Chowdhury, Z.Z.; Kazi, S.N.; Johan, M.R.; Akram, N.; Oon, C.S. Effect of ZnO-water based nanofluids from sonochemical synthesis method on heat transfer in a circular flow passage. Int. Commun. Heat Mass Transf. 2020, $114,104591$. [CrossRef]

105. Subhedar, D.G.; Ramani, B.M.; Gupta, A. Experimental investigation of heat transfer potential of $\mathrm{Al}_{2} \mathrm{O}_{3} / \mathrm{Water}^{-M o n o}$ Ethylene Glycol nanofluids as a car radiator coolant. Case Stud. Therm. Eng. 2018, 11, 26-34. [CrossRef]

106. Goudarzi, K.; Jamali, H. Heat transfer enhancement of $\mathrm{Al}_{2} \mathrm{O}_{3}$-EG nanofluid in a car radiator with wire coil inserts. Appl. Therm. Eng. 2017, 118, 510-517. [CrossRef]

107. Eid, M.R.; Al-Hossainy, A.F. Synthesis, DFT calculations, and heat transfer performance large-surface $\mathrm{TiO}_{2}$ : Ethylene glycol nanofluid and coolant applications. Eur. Phys. J. Plus 2020, 135, 1-19. [CrossRef]

108. Krishnakumar, T.S.; Sheeba, A.; Mahesh, V.; Jose Prakash, M. Heat transfer studies on ethylene glycol/water nanofluid containing $\mathrm{TiO}_{2}$ nanoparticles. Int. J. Refrig. 2019, 102, 55-61. [CrossRef]

109. Islam, M.R.; Shabani, B.; Rosengarten, G. Electrical and Thermal Conductivities of 50/50 Water-ethylene Glycol Based TiO 2 Nanofluids to be Used as Coolants in PEM Fuel Cells. Energy Procedia 2017, 110, 101-108. [CrossRef]

110. Colangelo, G.; Raho, B.; Milanese, M.; Risi, A. De Numerical Evaluation of a HVAC System Based on a High-Performance Heat Transfer Fluid. Energies 2021, 14, 3298. [CrossRef]

111. Iacobazzi, F. A critical analysis of clustering phenomenon in $\mathrm{Al}_{2} \mathrm{O}_{3}$ nanofluids. J. Therm. Anal. Calorim. 2019, 9, 371-377. [CrossRef]

112. Javed, M.; Shaik, A.H.; Khan, T.A.; Imran, M.; Aziz, A.; Ansari, A.R.; Chandan, M.R. Synthesis of stable waste palm oil based $\mathrm{CuO}$ nanofluid for heat transfer applications. Heat Mass Transf. Stoffuebertragung 2018, 54, 3739-3745. [CrossRef]

113. Gkountas, A.A.; Benos, L.T.; Sofiadis, G.N.; Sarris, I.E. A printed-circuit heat exchanger consideration by exploiting an $\mathrm{Al}_{2} \mathrm{O}_{3}$ water nanofluid: Effect of the nanoparticles interfacial layer on heat transfer. Therm. Sci. Eng. Prog. 2021, 22, 100818. [CrossRef]

114. Du, R.; Jiang, D.D.; Wang, Y.; Wei Shah, K. An experimental investigation of CuO/water nanofluid heat transfer in geothermal heat exchanger. Energy Build. 2020, 227, 110402. [CrossRef]

115. Zhong, D.; Zhong, H.; Wen, T. Investigation on the thermal properties, heat transfer and flow performance of a highly selfdispersion $\mathrm{TiO}_{2}$ nanofluid in a multiport mini channel. Int. Commun. Heat Mass Transf. 2020, 117, 104783. [CrossRef] 
116. Wen, T.; Lu, L.; Zhong, H.; Shen, B. Thermal properties measurement and performance evaluation of water/ZnO nanofluid in a mini channel with offset fins. Int. J. Heat Mass Transf. 2020, 162, 120361. [CrossRef]

117. Shahrestani, M.I.; Maleki, A.; Shadloo, M.S.; Tlili, I. Numerical Investigation of Forced Convective Heat Transfer and Performance Evaluation Criterion of $\mathrm{Al}_{2} \mathrm{O}_{3} /$ Water Nanofluid Flow inside an Axisymmetric Microchannel. Symmetry. 2020, 12, 120. [CrossRef]

118. Zhu, D.; Wang, L.; Yu, W.; Xie, H. Intriguingly high thermal conductivity increment for CuO nanowires contained nanofluids with low viscosity. Sci. Rep. 2018, 8, 1-12. [CrossRef]

119. Ahmadi, M.A.; Ahmadi, M.H.; Fahim Alavi, M.; Nazemzadegan, M.R.; Ghasempour, R.; Shamshirband, S. Determination of thermal conductivity ratio of $\mathrm{CuO} /$ ethylene glycol nanofluid by connectionist approach. J. Taiwan Inst. Chem. Eng. 2018, 91, 383-395. [CrossRef]

120. Hemmat Esfe, M.; Nadooshan, A.A.; Arshi, A.; Alirezaie, A. Convective heat transfer and pressure drop of aqua based TiO 2 nanofluids at different diameters of nanoparticles: Data analysis and modeling with artificial neural network. Phys. E LowDimensional Syst. Nanostructures 2018, 97, 155-161. [CrossRef]

121. Ding, M.; Liu, C.; Rao, Z. Experimental investigation on heat transfer characteristic of $\mathrm{TiO}_{2}-\mathrm{H}_{2} \mathrm{O}$ nanofluid in microchannel for thermal energy storage. Appl. Therm. Eng. 2019, 160, 114024. [CrossRef]

122. Milanese, M.; Colangelo, G.; Cretì, A.; Lomascolo, M.; Iacobazzi, F.; Risi, A. De Solar Energy Materials \& Solar Cells Optical absorption measurements of oxide nanoparticles for application as nano fl uid in direct absorption solar power systems-Part I: Water-based nano fl uids behavior. Sol. Energy Mater. Sol. Cells 2016, 147, 315-320. [CrossRef]

123. Milanese, M.; Colangelo, G.; Cretì, A.; Lomascolo, M.; Iacobazzi, F.; Risi, A. De Solar Energy Materials \& Solar Cells Optical absorption measurements of oxide nanoparticles for application as nano $\mathrm{fl}$ uid in direct absorption solar power systems-Part II: $\mathrm{ZnO}, \mathrm{CeO}_{2}, \mathrm{Fe}_{2} \mathrm{O}_{3}$ nanoparticles behavior. Sol. Energy Mater. Sol. Cells 2016, 147, 321-326. [CrossRef]

124. Potenza, M.; Milanese, M.; Colangelo, G.; Risi, A. De Experimental investigation of transparent parabolic trough collector based on gas-phase nanofluid. Appl. Energy 2017, 203, 560-570. [CrossRef]

125. Wen, D.; Lin, G.; Vafaei, S.; Zhang, K. Review of nanofluids for heat transfer applications. Particuology 2009, 7, 141-150. [CrossRef]

126. Nakhchi, M.E.; Esfahani, J.A. Numerical investigation of turbulent $\mathrm{Cu}$-water nanofluid in heat exchanger tube equipped with perforated conical rings. Adv. Powder Technol. 2019, 30, 1338-1347. [CrossRef]

127. Mebarek-Oudina, F.; Bessaih, R. Numerical simulation of natural convection heat transfer of copper-water nanofluid in a vertical cylindrical annulus with heat sources. Thermophys. Aeromechanics 2019, 26, 325-334. [CrossRef]

128. Gholamalipour, P.; Siavashi, M.; Doranehgard, M.H. Eccentricity effects of heat source inside a porous annulus on the natural convection heat transfer and entropy generation of Cu-water nanofluid. Int. Commun. Heat Mass Transf. 2019, $109,104367$. [CrossRef]

129. Saleem, S.; Qasin, M.; Alderremy, A.A.; Noreen, S. Heat transfer enhancement using different shapes of Cu nanoparticles in the flow of water based nanofluid. Phys. Scr. 2020, 95, 055209. [CrossRef]

130. Hadavand, M.; Yousefzadeh, S.; Akbari, O.A.; Pourfattah, F.; Nguyen, H.M.; Asadi, A. A numerical investigation on the effects of mixed convection of Ag-water nanofluid inside a sim-circular lid-driven cavity on the temperature of an electronic silicon chip. Appl. Therm. Eng. 2019, 162, 114298. [CrossRef]

131. Mir, S.; Akbari, O.A.; Toghraie, D.; Sheikhzadeh, G.; Marzban, A.; Mir, S.; Talebizadehsardari, P. A comprehensive study of two-phase flow and heat transfer of water/Ag nanofluid in an elliptical curved minichannel. Chin. J. Chem. Eng. 2020, $28,383-402$. [CrossRef]

132. Saleh, B.; Sundar, L.S. Experimental study on heat transfer, friction factor, entropy and exergy efficiency analyses of a corrugated plate heat exchanger using Ni/water nanofluids. Int. J. Therm. Sci. 2021, 165, 106935. [CrossRef]

133. Hemmat Esfe, M.; Saedodin, S.; Wongwises, S.; Toghraie, D. An experimental study on the effect of diameter on thermal conductivity and dynamic viscosity of Fe/water nanofluids. J. Therm. Anal. Calorim. 2015, 119, 1817-1824. [CrossRef]

134. Khoshvaght-Aliabadi, M.; Davoudi, S.; Dibaei, M.H. Performance of agitated-vessel U tube heat exchanger using spiky twisted tapes and water based metallic nanofluids. Chem. Eng. Res. Des. 2018, 133, 26-39. [CrossRef]

135. Mahmoudi, A.H.; Shahi, M.; Raouf, A.H.; Ghasemian, A. Numerical study of natural convection cooling of horizontal heat source mounted in a square cavity filled with nanofluid. Int. Commun. Heat Mass Transf. 2010, 37, 1135-1141. [CrossRef]

136. Ashorynejad, H.R.; Mohamad, A.A.; Sheikholeslami, M. Magnetic field effects on natural convection flow of a nanofluid in a horizontal cylindrical annulus using Lattice Boltzmann method. Int. J. Therm. Sci. 2013, 64, 240-250. [CrossRef]

137. Roszko, A.; Fornalik-Wajs, E.; Donizak, J.; Wajs, J.; Kraszewska, A.; Pleskacz, L.; Kenjeres, S. Magneto-thermal convection of low concentration nanofluids. MATEC Web Conf. 2014, 18, 1-8. [CrossRef]

138. Fornalik-Wajs, E.; Roszko, A.; Donizak, J. Nanofluid flow driven by thermal and magnetic forces—Experimental and numerical studies. Energy 2020, 201. [CrossRef]

139. Mishra, G.; Dash, B.; Pandey, S. Layered double hydroxides: A brief review from fundamentals to application as evolving biomaterials. Appl. Clay Sci. 2018, 153, 172-186. [CrossRef]

140. Chakraborty, S.; Sarkar, I.; Ashok, A.; Sengupta, I.; Pal, S.K.; Chakraborty, S. Synthesis of Cu-Al LDH nanofluid and its application in spray cooling heat transfer of a hot steel plate. Powder Technol. 2018, 335, 285-300. [CrossRef]

141. Tiara, A.M.; Chakraborty, S.; Sarkar, I.; Pal, S.K.; Chakraborty, S. Heat transfer in jet impingement on a hot steel surface using surfactant based Cu-Al layered double hydroxide nanofluid. Int. J. Heat Mass Transf. 2016, 101, 825-833. [CrossRef] 
142. Chakraborty, S.; Sarkar, I.; Ashok, A.; Sengupta, I.; Pal, S.K.; Chakraborty, S. Thermo-physical properties of Cu-Zn-Al LDH nanofluid and its application in spray cooling. Appl. Therm. Eng. 2018, 141, 339-351. [CrossRef]

143. Ponnada, S.; Subrahmanyam, T.; Naidu, S.V. An experimental investigation on heat transfer and friction factor of Silicon Carbide/water nanofluids in a circular tube. Energy Procedia 2019, 158, 5156-5161. [CrossRef]

144. Al-Waeli, A.H.A.; Sopian, K.; Chaichan, M.T.; Kazem, H.A.; Hasan, H.A.; Al-Shamani, A.N. An experimental investigation of SiC nanofluid as a base-fluid for a photovoltaic thermal PV/T system. Energy Convers. Manag. 2017, 142, 547-558. [CrossRef]

145. Verrilli, F.; Srinivasan, S.; Gambino, G.; Canelli, M.; Himanka, M.; Del Vecchio, C.; Sasso, M.; Glielmo, L. Model Predictive Control-Based Optimal Operations of District Heating System with Thermal Energy Storage and Flexible Loads. IEEE Trans. Autom. Sci. Eng. 2017, 14, 547-557. [CrossRef]

146. Jóźwiak, B.; Dzido, G.; Kolanowska, A.; Jędrysiak, R.G.; Zorębski, E.; Greer, H.F.; Dzida, M.; Boncel, S. From lab and up: Superior and economic heat transfer performance of ionanofluids containing long carbon nanotubes and 1-ethyl-3-methylimidazolium thiocyanate. Int. J. Heat Mass Transf. 2021, 172. [CrossRef]

147. Moradi, A.; Toghraie, D.; Isfahani, A.H.M.; Hosseinian, A. An experimental study on MWCNT-water nanofluids flow and heat transfer in double-pipe heat exchanger using porous media. J. Therm. Anal. Calorim. 2019, 137, 1797-1807. [CrossRef]

148. Sarafraz, M.M.; Nikkhah, V.; Nakhjavani, M.; Arya, A. Fouling formation and thermal performance of aqueous carbon nanotube nanofluid in a heat sink with rectangular parallel microchannel. Appl. Therm. Eng. 2017, 123, 29-39. [CrossRef]

149. Fan, L.W.; Li, J.Q.; Wu, Y.Z.; Zhang, L.; Yu, Z.T. Pool boiling heat transfer during quenching in carbon nanotube (CNT)-based aqueous nanofluids: Effects of length and diameter of the CNTs. Appl. Therm. Eng. 2017, 122, 555-565. [CrossRef]

150. Abdeen, D.H.; Atieh, M.A.; Merzougui, B.; Khalfaoui, W. Corrosion evaluation of 316L stainless steel in CNT-water nanofluid: Effect of CNTs loading. Materials 2019, 12, 1634. [CrossRef] [PubMed]

151. Selvam, C.; Mohan Lal, D.; Harish, S. Enhanced heat transfer performance of an automobile radiator with graphene based suspensions. Appl. Therm. Eng. 2017, 123, 50-60. [CrossRef]

152. Sadri, R.; Hosseini, M.; Kazi, S.N.; Bagheri, S.; Zubir, N.; Ahmadi, G.; Dahari, M.; Zaharinie, T. A novel, eco-friendly technique for covalent functionalization of graphene nanoplatelets and the potential of their nanofluids for heat transfer applications. Chem. Phys. Lett. 2017, 675, 92-97. [CrossRef]

153. Sözen, A.; Filiz, Ç.; Aytaç, İ.; Martin, K.; Ali, H.M.; Boran, K.; Yetişken, Y. Upgrading of the Performance of an Air-to-Air Heat Exchanger Using Graphene/Water Nanofluid. Int. J. Thermophys. 2021, 42, 1-15. [CrossRef]

154. Selvam, C.; Solaimalai Raja, R.; Mohan Lal, D.; Harish, S. Overall heat transfer coefficient improvement of an automobile radiator with graphene based suspensions. Int. J. Heat Mass Transf. 2017, 115, 580-588. [CrossRef]

155. Zhan, X.; Si, C.; Zhou, J.; Sun, Z. MXene and MXene-based composites: Synthesis, properties and environment-related applications. Nanoscale Horizons 2020, 5, 235-258. [CrossRef]

156. Bao, Z.; Bing, N.; Zhu, X.; Xie, H.; Yu, W. Ti ${ }_{3} \mathrm{C}_{2} \mathrm{~T}_{\mathrm{x}} \mathrm{MXene}$ contained nanofluids with high thermal conductivity, super colloidal stability and low viscosity. Chem. Eng. J. 2021, 406, 126390. [CrossRef]

157. Aslfattahi, N.; Samylingam, L.; Abdelrazik, A.S.; Arifutzzaman, A.; Saidur, R. MXene based new class of silicone oil nanofluids for the performance improvement of concentrated photovoltaic thermal collector. Sol. Energy Mater. Sol. Cells 2020, $211,110526$. [CrossRef]

158. Samylingam, L.; Aslfattahi, N.; Saidur, R.; Yahya, S.M.; Afzal, A.; Arifutzzaman, A.; Tan, K.H.; Kadirgama, K. Thermal and energy performance improvement of hybrid PV/T system by using olein palm oil with MXene as a new class of heat transfer fluid. Sol. Energy Mater. Sol. Cells 2020, 218, 110754. [CrossRef]

159. Rubbi, F.; Habib, K.; Saidur, R.; Aslfattahi, N.; Yahya, S.M.; Das, L. Performance optimization of a hybrid PV/T solar system using Soybean oil/MXene nanofluids as A new class of heat transfer fluids. Sol. Energy 2020, 208, 124-138. [CrossRef]

160. Hassan, M.; Marin, M.; Ellahi, R.; Alamri, S.Z. Exploration of convecti ve heat transfer and flow characteristics synthesis by Cu-Ag/Water hybrid-nanofluids. Heat Transf. Res. 2018, 49, 1837-1848. [CrossRef]

161. Akram, J.; Akbar, N.S.; Tripathi, D. A Theoretical Investigation on the Heat Transfer Ability of Water-Based Hybrid (Ag-Au) Nanofluids and Ag Nanofluids Flow Driven by Electroosmotic Pumping Through a Microchannel. Arab. J. Sci. Eng. 2021, 46, 2911-2927. [CrossRef]

162. Hayat, T.; Nadeem, S. Heat transfer enhancement with Ag-CuO/water hybrid nanofluid. Results Phys. 2017, 7, 2317-2324. [CrossRef]

163. Ghadikolaei, S.S.; Yassari, M.; Sadeghi, H.; Hosseinzadeh, K.; Ganji, D.D. Investigation on thermophysical properties of TiO ${ }_{2}-$ $\mathrm{Cu} / \mathrm{H}_{2} \mathrm{O}$ hybrid nanofluid transport dependent on shape factor in MHD stagnation point flow. Powder Technol. 2017, 322, 428-438. [CrossRef]

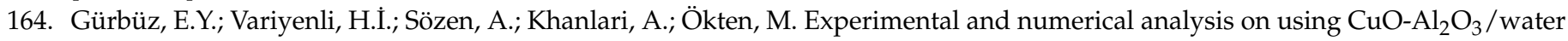
hybrid nanofluid in a U-type tubular heat exchanger. Int. J. Numer. Methods Heat Fluid Flow 2021, 31, 519-540. [CrossRef]

165. Minea, A.A. Hybrid nanofluids based on $\mathrm{Al}_{2} \mathrm{O}_{3}, \mathrm{TiO}_{2}$ and $\mathrm{SiO}_{2}$ : Numerical evaluation of different approaches. Int. J. Heat Mass Transf. 2017, 104, 852-860. [CrossRef]

166. Gupta, N.; Gupta, S.M.; Sharma, S.K. Preparation of stable metal/COOH-MWCNT hybrid nanofluid. Mater. Today Proc. 2019, 36, 649-656. [CrossRef]

167. Kumar, V.; Sarkar, J. Particle ratio optimization of $\mathrm{Al}_{2} \mathrm{O}_{3}-\mathrm{MWCNT}$ hybrid nanofluid in minichannel heat sink for best hydrothermal performance. Appl. Therm. Eng. 2020, 165, 114546. [CrossRef] 
168. Hussien, A.A.; Abdullah, M.Z.; Yusop, N.M.; Al-Nimr, M.A.; Atieh, M.A.; Mehrali, M. Experiment on forced convective heat transfer enhancement using MWCNTs/GNPs hybrid nanofluid and mini-tube. Int. J. Heat Mass Transf. 2017, 115, $1121-1131$. [CrossRef]

169. Said, Z.; Abdelkareem, M.A.; Rezk, H.; Nassef, A.M.; Atwany, H.Z. Stability, thermophysical and electrical properties of synthesized carbon nanofiber and reduced-graphene oxide-based nanofluids and their hybrid along with fuzzy modeling approach. Powder Technol. 2020, 364, 795-809. [CrossRef]

170. Wang, J.; Guan, Z.; Gurgenci, H.; Hooman, K.; Veeraragavan, A.; Kang, X. Computational investigations of heat transfer to supercritical $\mathrm{CO}_{2}$ in a large horizontal tube. Energy Convers. Manag. 2018, 157, 536-548. [CrossRef]

171. Aguilar, R.; Valenzuela, L.; Avila-Marin, A.L.; Garcia-Ybarra, P.L. Simplified heat transfer model for parabolic trough solar collectors using supercritical $\mathrm{CO}_{2}$. Energy Convers. Manag. 2019, 196, 807-820. [CrossRef]

172. Wang, K.Z.; Xu, X.X.; Liu, C.; Bai, W.J.; Dang, C. bin Experimental and numerical investigation on heat transfer characteristics of supercritical $\mathrm{CO}_{2}$ in the cooled helically coiled tube. Int. J. Heat Mass Transf. 2017, 108, 1645-1655. [CrossRef]

173. Zhang, S.; Xu, X.; Liu, C.; Liu, X.; Ru, Z.; Dang, C. Experimental and numerical comparison of the heat transfer behaviors and buoyancy effects of supercritical CO2 in various heating tubes. Int. J. Heat Mass Transf. 2020, 149. [CrossRef]

174. Wang, K.; Zhang, Z.D.; Li, M.J.; Min, C.H. A coupled optical-thermal-fluid-mechanical analysis of parabolic trough solar receivers using supercritical $\mathrm{CO}_{2}$ as heat transfer fluid. Appl. Therm. Eng. 2021, 183, 116154. [CrossRef]

175. Guo, P.; Liu, S.; Yan, J.; Wang, J.; Zhang, Q. Experimental study on heat transfer of supercritical $\mathrm{CO}_{2}$ flowing in a mini tube under heating conditions. Int. J. Heat Mass Transf. 2020, 153. [CrossRef]

176. Zhang, L.; Jiang, P.; Wang, Z.; Xu, R. Convective heat transfer of supercritical $\mathrm{CO}_{2}$ in a rock fracture for enhanced geothermal systems. Appl. Therm. Eng. 2017, 115, 923-936. [CrossRef]

177. Khalesi, J.; Sarunac, N.; Razzaghpanah, Z. Supercritical $\mathrm{CO}_{2}$ conjugate heat transfer and flow analysis in a rectangular microchannel subject to uniformly heated substrate wall. Therm. Sci. Eng. Prog. 2020, 19, 100596. [CrossRef]

178. American National Standards Institute; ASHRAE. Designation and Safety Classification of Refrigerants; ANSI/ASHRAE Standard 34-2019; ANSI: Washington, DC, USA; ASHRAE: Atlanta, GA, USA, 2019; Volume 2019, pp. 1-52.

179. Bellos, E.; Tzivanidis, C. A comparative study of CO2 refrigeration systems. Energy Convers. Manag. X 2019, 1, 100002. [CrossRef]

180. Xu, X.; Wang, X.; Li, P.; Li, Y.; Hao, Q.; Xiao, B.; Elsentriecy, H.; Gervasio, D. Experimental Test of Properties of KCl-MgCl2 Eutectic Molten Salt for Heat Transfer and Thermal Storage Fluid in Concentrated Solar Power Systems. J. Sol. Energy Eng. Trans. ASME 2018, 140, 1-9. [CrossRef]

181. Liu, T.; Xu, X.; Liu, W.; Zhuang, X. Corrosion of alloys in high temperature molten-salt heat transfer fluids with air as the cover gas. Sol. Energy 2019, 191, 435-448. [CrossRef]

182. Fuqiang, W.; Huijian, J.; Hao, W.; Ziming, C.; Jianyu, T.; Yuan, Y.; Yuhang, S.; Wenjie, Z. Radiative, conductive and laminar convective coupled heat transfer analysis of molten salts based on finite element method. Appl. Therm. Eng. 2018, 131, 19-29. [CrossRef]

183. Kuchibhotla, A.; Banerjee, D.; Dhir, V. Forced convection heat transfer of molten Salts: A review. Nucl. Eng. Des. 2020, $362,110591$. [CrossRef]

184. Zou, L.L.; Chen, X.; Wu, Y.T.; Wang, X.; Ma, C.F. Experimental study of thermophysical properties and thermal stability of quaternary nitrate molten salts for thermal energy storage. Sol. Energy Mater. Sol. Cells 2019, 190, 12-19. [CrossRef]

185. Vaka, M.; Walvekar, R.; Jagadish, P.; Khalid, M.; Mubarak, N.M.; Panchal, H. High-temperature molten salts optimisation using mixture design for energy storage application. J. Energy Storage 2020, 32, 101981. [CrossRef]

186. Chen, Y.Y.; Zhao, C.Y. Thermophysical properties of $\mathrm{Ca}\left(\mathrm{NO}_{3}\right)_{2}-\mathrm{NaNO}_{3}-\mathrm{KNO}_{3}$ mixtures for heat transfer and thermal storage. Sol. Energy 2017, 146, 172-179. [CrossRef]

187. Trabelsi, S.E.; Qoaider, L.; Guizani, A. Investigation of using molten salt as heat transfer fluid for dry cooled solar parabolic trough power plants under desert conditions. Energy Convers. Manag. 2018, 156, 253-263. [CrossRef]

188. Rizvi, S.M.M.; Shin, D. Mechanism of heat capacity enhancement in molten salt nanofluids. Int. J. Heat Mass Transf. 2020, 161, 120260. [CrossRef]

189. Chen, X.; Wu, Y.T.; Zhang, L.D.; Wang, X.; Ma, C.F. Experimental study on thermophysical properties of molten salt nanofluids prepared by high-temperature melting. Sol. Energy Mater. Sol. Cells 2019, 191, 209-217. [CrossRef]

190. Xiong, Y.; Sun, M.; Wu, Y.; Xu, P.; Xu, Q.; Li, C.; Ding, Y.; Ma, C. Effects of Synthesis Methods on Thermal Performance of Nitrate Salt Nanofluids for Concentrating Solar Power. Energy Fuels 2020, 34, 11606-11619. [CrossRef]

191. Ying, Z.; He, B.; Su, L.; Kuang, Y.; He, D.; Lin, C. Convective heat transfer of molten salt-based nanofluid in a receiver tube with non-uniform heat flux. Appl. Therm. Eng. 2020, 181, 115922. [CrossRef]

192. Wei, X.; Yin, Y.; Qin, B.; Wang, W.; Ding, J.; Lu, J. Preparation and enhanced thermal conductivity of molten salt nanofluids with nearly unaltered viscosity. Renew. Energy 2020, 145, 2435-2444. [CrossRef]

193. Singh, S.K.; Savoy, A.W. Ionic liquids synthesis and applications: An overview. J. Mol. Liq. 2020, 297, 112038. [CrossRef]

194. Shamshina, J.L.; Zavgorodnya, O.; Rogers, R.D. Ionic Liquids, 3rd ed.; Elsevier Inc.: Amsterdam, The Netherlands, 2019; ISBN 9780081019832.

195. Oster, K.; Jacquemin, J.; Hardacre, C.; Ribeiro, A.P.C.; Elsinawi, A. Further development of the predictive models for physical properties of pure ionic liquids: Thermal conductivity and heat capacity. J. Chem. Thermodyn. 2018, 118, 1-15. [CrossRef] 
196. Oster, K.; Goodrich, P.; Jacquemin, J.; Hardacre, C.; Ribeiro, A.P.C.; Elsinawi, A. A new insight into pure and water-saturated quaternary phosphonium-based carboxylate ionic liquids: Density, heat capacity, ionic conductivity, thermogravimetric analysis, thermal conductivity and viscosity. J. Chem. Thermodyn. 2018, 121, 97-111. [CrossRef]

197. Paul, T.C.; Morshed, A.K.M.M.; Fox, E.B.; Khan, J.A. Enhanced thermophysical properties of NEILs as heat transfer fluids for solar thermal applications. Appl. Therm. Eng. 2017, 110, 1-9. [CrossRef]

198. Hosseinghorbani, A.; Mozaffarian, M.; Pazuki, G. Application of graphene oxide IoNanofluid as a superior heat transfer fluid in concentrated solar power plants. Int. Commun. Heat Mass Transf. 2020, 111. [CrossRef]

199. Das, L.; Habib, K.; Saidur, R.; Aslfattahi, N.; Yahya, S.M.; Rubbi, F. Improved thermophysical properties and energy efficiency of aqueous ionic liquid/mxene nanofluid in a hybrid pv/t solar system. Nanomaterials 2020, 10, 1732. [CrossRef] [PubMed]

200. Yang, W.; Zhang, L.; Guo, Y.; Jiang, Z.; He, F.; Xie, C.; Fan, J.; Wu, J.; Zhang, K. Novel segregated-structure phase change materials composed of paraffin-graphene microencapsules with high latent heat and thermal conductivity. J. Mater. Sci. 2018, 53, 2566-2575. [CrossRef]

201. Du, K.; Calautit, J.; Wang, Z.; Wu, Y.; Liu, H. A review of the applications of phase change materials in cooling, heating and power generation in different temperature ranges. Appl. Energy 2018, 220, 242-273. [CrossRef]

202. Ghalambaz, M.; Mehryan, S.A.M.; Hajjar, A.; Veismoradi, A. Unsteady natural convection flow of a suspension comprising Nano-Encapsulated Phase Change Materials (NEPCMs) in a porous medium. Adv. Powder Technol. 2020, 31, 954-966. [CrossRef]

203. Chananipoor, A.; Azizi, Z.; Raei, B.; Tahmasebi, N. Optimization of the thermal performance of nano-encapsulated phase change material slurry in double pipe heat exchanger: Design of experiments using response surface methodology (RSM). J. Build. Eng. 2021, 34, 101929. [CrossRef]

204. Ghalambaz, M.; Mehryan, S.A.M.; Zahmatkesh, I.; Chamkha, A. Free convection heat transfer analysis of a suspension of nano-encapsulated phase change materials (NEPCMs) in an inclined porous cavity. Int. J. Therm. Sci. 2020, 157, 106503. [CrossRef]

205. Nomura, T.; Sheng, N.; Zhu, C.; Saito, G.; Hanzaki, D.; Hiraki, T.; Akiyama, T. Microencapsulated phase change materials with high heat capacity and high cyclic durability for high-temperature thermal energy storage and transportation. Appl. Energy 2017, 188, 9-18. [CrossRef]

206. Khan, A.; Ali, H.M.; Nazir, R.; Ali, R.; Munir, A.; Ahmad, B.; Ahmad, Z. Experimental investigation of enhanced heat transfer of a car radiator using $\mathrm{ZnO}$ nanoparticles in $\mathrm{H}_{2} \mathrm{O}$-ethylene glycol mixture. J. Therm. Anal. Calorim. 2019, 138, 3007-3021. [CrossRef]

207. Fazeli, I.; Sarmasti Emami, M.R.; Rashidi, A. Investigation and optimization of the behavior of heat transfer and flow of MWCNT$\mathrm{CuO}$ hybrid nanofluid in a brazed plate heat exchanger using response surface methodology. Int. Commun. Heat Mass Transf. 2021, 122, 105175. [CrossRef]

208. Qiu, Y.; Li, M.J.; Li, M.J.; Zhang, H.H.; Ning, B. Numerical and experimental study on heat transfer and flow features of representative molten salts for energy applications in turbulent tube flow. Int. J. Heat Mass Transf. 2019, 135, 732-745. [CrossRef]

209. Yee, R.P.; Hermes, C.J.L. A thermodynamic study of water-based nanosuspensions as secondary heat transfer fluids in refrigeration systems. Int. J. Refrig. 2018, 89, 104-111. [CrossRef]

210. Mondejar, M.E.; Andreasen, J.G.; Regidor, M.; Riva, S.; Kontogeorgis, G.; Persico, G.; Haglind, F. Prospects of the use of nanofluids as working fluids for organic Rankine cycle power systems. Energy Procedia 2017, 129, 160-167. [CrossRef]

211. Zhang, J.; Zhao, M.; Wang, G. Effects of heat transfer fluid and boundary conditions on temperature field of enhanced geothermal system. Petroleum 2021. [CrossRef]

212. Gagne-Boisvert, L.; Bernier, M. Comparison of the Energy Use for Different Heat Transfer Fluids in Geothermal Systems. In Proceedings of the IGSHPA Technical/Research Conference and Expo, Denver, CO, USA, 14-16 March 2017. [CrossRef]

213. Rane, M.V.; Tandale, M.S. Water-to-water heat transfer in tube-tube heat exchanger: Experimental and analytical study. Appl. Therm. Eng. 2005, 25, 2715-2729. [CrossRef]

214. Fares, M.; AL-Mayyahi, M.; AL-Saad, M. Heat transfer analysis of a shell and tube heat exchanger operated with graphene nanofluids. Case Stud. Therm. Eng. 2020, 18, 100584. [CrossRef]

215. Ahmed, M.S.; Elsaid, A.M. Effect of hybrid and single nanofluids on the performance characteristics of chilled water air conditioning system. Appl. Therm. Eng. 2019, 163, 114398. [CrossRef]

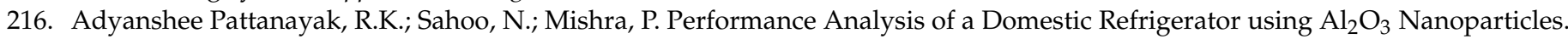
IOSR J. Mech. Civ. Eng. Ver. IV 2016, 12, 1684-2278. [CrossRef]

217. Sarkar, I.; Chakraborty, S.; Jha, J.M.; Pal, S.K.; Chakraborty, S. Ultrafast cooling of a hot steel plate using Cu-Al layered double hydroxide nanofluid jet. Int. J. Therm. Sci. 2017, 116, 52-62. [CrossRef]

218. Jha, J.M.; Sarkar, I.; Chakraborty, S.; Pal, S.K.; Chakraborty, S. Heat transfer from a hot moving steel plate by using Cu-Al layered double hydroxide nanofluid based air atomized spray. Exp. Heat Transf. 2017, 30, 500-516. [CrossRef]

219. Kwon, J.S.; Son, S.; Heo, J.Y.; Lee, J.I. Compact heat exchangers for supercritical $\mathrm{CO}_{2}$ power cycle application. Energy Convers. Manag. 2020, 209, 112666. [CrossRef]

220. Lei, Y.; Chen, Z. Cooling heat transfer and pressure drop of supercritical $\mathrm{CO}_{2}$ in wavy microchannels with consistent and opposite crests and troughs. Int. J. Refrig. 2020, 109, 64-81. [CrossRef]

221. Henchoz, S.; Favrat, D.; Girardin, L. District heating and cooling energy network using $\mathrm{CO}_{2}$ as a heat and mass transfer fluid. Heat Pump. Technol. Mag. 2018, 36, 19-21. 
222. Fritsch, A.; Frantz, C.; Uhlig, R. Techno-economic analysis of solar thermal power plants using liquid sodium as heat transfer fluid. Sol. Energy 2019, 177, 155-162. [CrossRef]

223. Yu, Q.; Lu, Y.; Zhang, C.; Wu, Y.; Sunden, B. Experimental and numerical study of natural convection in bottom-heated cylindrical cavity filled with molten salt nanofluids. J. Therm. Anal. Calorim. 2020, 141, 1207-1219. [CrossRef]

224. Yang, H.; Li, J.; Huang, Y.; Kwan, T.H.; Cao, J.; Pei, G. Feasibility research on a hybrid solar tower system using steam and molten salt as heat transfer fluid. Energy 2020, 205, 118094. [CrossRef]

225. Muñoz-Sánchez, B.; Nieto-Maestre, J.; Iparraguirre-Torres, I.; García-Romero, A.; Sala-Lizarraga, J.M. Molten salt-based nanofluids as efficient heat transfer and storage materials at high temperatures. An overview of the literature. Renew. Sustain. Energy Rev. 2018, 82, 3924-3945. [CrossRef]

226. Zahir, M.H.; Mohamed, S.A.; Saidur, R.; Al-Sulaiman, F.A. Supercooling of phase-change materials and the techniques used to mitigate the phenomenon. Appl. Energy 2019, 240, 793-817. [CrossRef]

227. Sun, X.; Medina, M.A.; Lee, K.O.; Jin, X. Laboratory assessment of residential building walls containing pipe-encapsulated phase change materials for thermal management. Energy 2018, 163, 383-391. [CrossRef]

228. Qiu, L.; Ouyang, Y.; Feng, Y.; Zhang, X. Review on micro/nano phase change materials for solar thermal applications. Renew. Energy 2019, 140, 513-538. [CrossRef]

229. Shyam Prasad, S.; Deepak Selvakumar, R. Heat transfer performance of $\mathrm{Al}_{2} \mathrm{O}_{3}-([\mathrm{C} 4 \mathrm{mim}][\mathrm{NTf} 2])$ nano-suspension in a 2-D channel for application in a flat plate solar collector. IOP Conf. Ser. Mater. Sci. Eng. 2019, 577. [CrossRef] 